\title{
Disturbances Due to the Motion of a Cylinder in a Two-Layer Liquid System
}

\author{
Lloyd H. Carpenter and Garbis H. Keulegan
}

(April 7, 1960)

\begin{abstract}
The disturbance created at the interface of a two-layer liquid system by the horizontal motion of a cylinder in the upper layer is studied for various sizes and shapes of cylinders, depths of the liquids, cylinder velocities, and density ratios. The disturbances fall into three categories. First, when the layers are of equal thickness, in most cases a train of progressive oscillatory waves is produced at the interface. Second, when the depth of the denser layer is much less than the depth of the fresh-water layer, the profile of the interface usually resembles that corresponding to positive internal solitary waves. Third, when the depth of the denser layer is much greater than the depth of the fresh-water layer, in most cases an internal hydraulic jump is produced. The characteristics of the disturbances in each category are related to the size of the cylinder, the depths of the liquids, the cylinder velocity, the density ratio, and the total distance of travel of the cylinder. A theoretical analysis is given for disturbances of the first eategory.
\end{abstract}

\section{Introduction}

Almost a century ago Stokes gave the theory of internal waves of infinitesimal height in a two-layer system, the lighter liquid resting on the heavier one $[1],{ }^{2}$ and about a quarter century later the problems of multilayer systems were considered by Webb [2], Grenhill [3], and Burnside [4]. Following these, the wave motions of hetrogeneous liquids with continuously varying density gradients in the vertical were taken up by Love [5], Rayleigh [6], and Lamb [7]. These studies relate to an endless succession of waves, standing or progressive, without reference to the generation of the disturbance such as would result from the motion of objects through a stratified medium or from the uniform flow of fluids over a ridge fixed on the bottom.

The first studies of the latter category go back to Ekman, who considered disturbances of the interface of a two-layer system initiated when a body is towed over the surface [8]. The occasion of the study was the classical account by Nansen of dead water experienced by the Fram during the North Polor Expedition near the coast of Siberia. Ekman approached the problen with much encouragement from Bjerknes both from an experimental and theoretical point of view. In addition to constituting the first serious attempt at model procedures in stratified fluids, the investigation is significant in two respects. First, working with a model of the Fram, Ekman showed that the internal waves brought into play an added resistance having a magnitude dependent on the ratio of draft to fresh water depth, the ratio of layer depths, and the proportionate density differences. The maximum values of the added resistances were obtained when the ratio of the velocity of the model to the velocity

1 Sponsored by the Office of Naval Research.

2 Figures in brackets indicate the literature references at the end of this paper. of long internal waves of the bilayer system attained the value 0.73 , and the added resistance gradually decreased for larger velocities of the model. Second, the question of the added resistance was considered using a method of approach originally adopted by Kelvin in a similar problem applied to a homogeneous fluid. In the evaluation the complete representation of the rufflement of the interface was avoided, and attention was focused only on the parts contributing to the resistance. In this theory the incidence of the maximum is correctly predicted.

The converse problem, that is the problem of a two-layer system moving over a ridge, was considered by Zeilon [9]. The investigation had its inspiration in the views of Pettersson to the effect that the internal boundary waves resulting from the interaction of the Atlantic tides on the irregular bottom configurations had a dominating influence upon the circulation of the Baltic. The problem investigated, thus, was the perturbed state of the interface owing to a ridge at the bottom of a two-layer system in simple harmonic horizontal motion. Experiments were carried out which were intended to verify in a qualitative sense the results of the lengthy mathematical analysis.

Among the recent studies the contributions of Robert Long have much to offer. A novel aspect is the first integration of the hydrodynamic equation for the two-dimensional case of nonviscous flow confined to the space between two rigid horizontal boundaries, the initial velocities (always horizontal) and the densities of the undisturbed regions being prescribed. Rigorous solutions were obtained for the cases where the liquid flows initially with uniform velocity and with linearly varying densities over a flat rectangular ridge [10]. The analysis was repeated for a smooth object, and experiments were made which showed a wave motion giving qualitative confirmation of the theoretical results [11]. The interpretations of the theory and ex- 
periments have numerous aspects, but it should suf fice to state here that in general the criterion of the densimetric Froude number (to be defined later) equaling $1 / \pi$ divides the types of internal flow. Of particular interest is the examination, experimental and theoretical, of the flow of two superimposed layers over a ridge. Internal waves were generated when the ridge was of small projection, whereas with the much enlarged and elevated ridges the most significant event was the formation of leeward hy draulic jumps [12].

The question of critical flows and the manifestation of hydraulic jumps in a bilayer or a multilayer system is an important one. The significance of the occurrence to meteorology was first emphasized by Tepper [13]. The matter has been approached from various points of view by Rossby [14], Craya [15], Benton [16], Yih [17], and others.

The matter of finite amplitude waves for a twolayer system has been considered by Keulegan and Long [18, 19]. Theory predicts the existence of positive internal solitary waves for the condition that the upper layer has the greater depth. The experiments by Keulegan tend to confirm the results of theory relating to shape and dependence of velocity of propagation on wave height [20].

In common with the disturbances produced in a nonhomogeneous system by liquid moving over ridges on the bottom or of objects being towed on the surface, other related phenomena would be associated with bodies moving through the interior of the medium. The simplest situation arises with the two-dimensional flow of a two-layer system, and this is the subject of the present study. We are here concerned with disturbances of the interface produced by a cylinder moving with constant hori. zontal velocity in the upper layer as illustrated in figure 1 . The liquids are initially at rest, and the density difference is small. Experiments are made with various depths of the layers, sizes and shapes of cylinders, and cylinder velocities. Further experi-ments with continuous density gradients will be described in a later report.

\section{Apparatus and Procedures}

The experimental channel is $26.25 \mathrm{~m}$ long, $23.3 \mathrm{~cm}$ wide, $57 \mathrm{~cm}$ deep, and is made up of 21 glass-paneled sections, each $125 \mathrm{~cm}$ long. The salt water was mixed and dyed with acid chrome blue and then admitted to the channel to a depth of 2 or $3 \mathrm{~cm}$ above the desired level of the interface. The salt water was circulated in the channel by a circulating pump to assure uniform density of the salt layer. After the mixing was complete and the circulation had subsided, fresh water for the upper layer was introduced at the center of the channel through the device shown in figure 2 . The device was lowered until the lips touched the water surface. The fresh water was introduced very slowly at first so as to produce as little mixing as possible. A siphon was placed at each end of the channel to remove the mixed liquid at the interface. The process was continued until the interface had been reduced to the desired depth, $h$, and the total depth had increased to the desired value, $h+h^{\prime}$ (see fig. 5).

After the channel was filled and all internal mo. tion of the liquid subsided, the density distribution was determined by traversing vertically with a salinity electrode. Various shunts were used in the circuit for greater accuracy in determining salinities within various ranges. The electrode was calibrated with each shunt so the milliampere current readings could be used to determine the density of salt solutions. An example of the vertical distri-

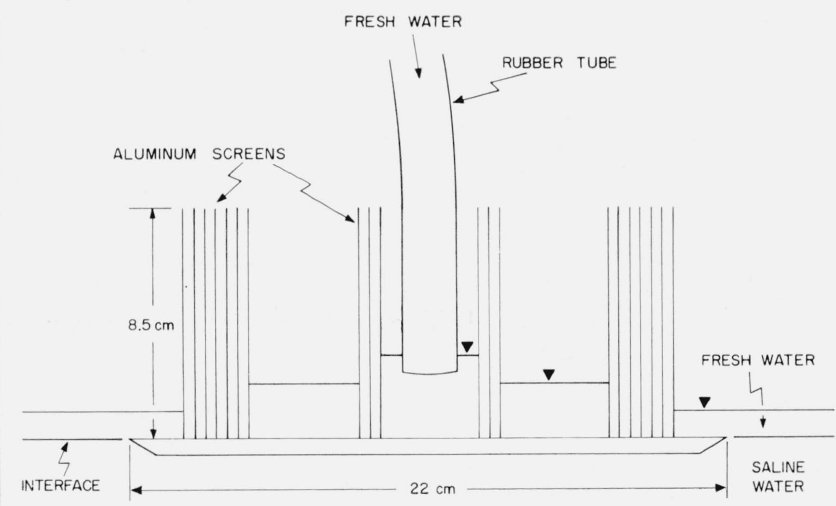

FiguRE 2. Longitudinal section of device for introducing fresh water on top of saline water.

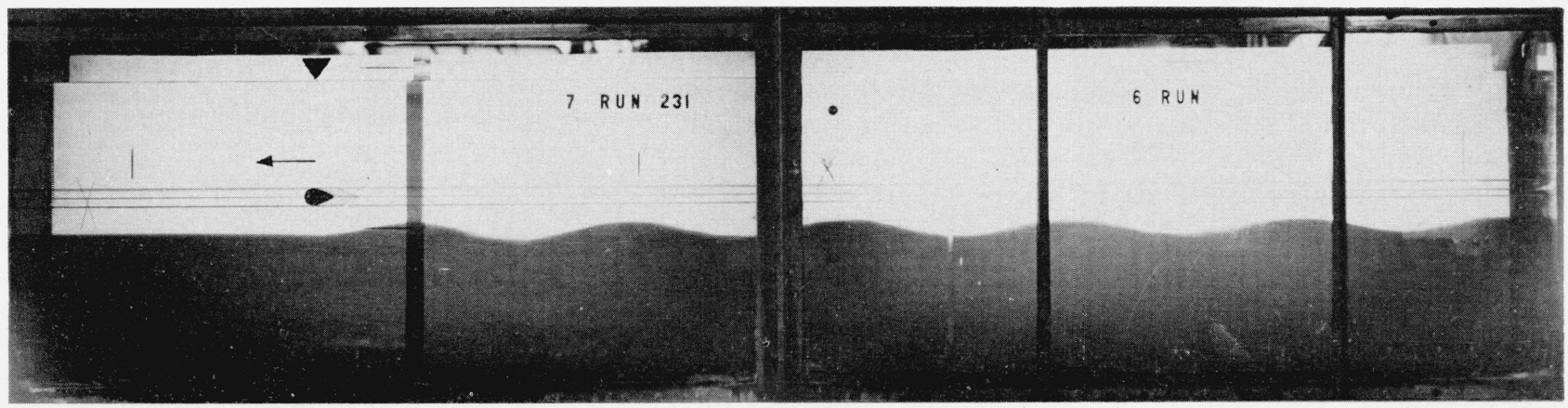

FIGURE 1. Disturbance at the interface between two liquids produced by a cylinder moving with constant velocity in the upper layer.

The symbol $\boldsymbol{\nabla}$ indicates the water surface. 
bution of density is given in figure 3 . The thickness of the layer of mixed liquid was 1 to $1.5 \mathrm{~cm}$ in all cases which was small compared to the depths of the fresh and salt layers.

Cylinders of three different diameters, 2.54, 5.08, and $10.16 \mathrm{~cm}$, and three different shapes, circular, lenticular, and tear drop, were used. The lenticular and tear drop shapes are shown in figure 4. In all cases the center of the cylinder was placed 30.0 $\mathrm{cm}$ from the bottom.

The cylinders were towed by an electric motor through a variable speed transmission, a system of pulleys, and two $0.81-\mathrm{mm}$ phosphor bronze towing wires. Four 1.22-mm piano wires under tension were used as guide wires to prevent vertical oscillations of the cylinder. Through the variable speed transmission any velocity from 0 to over $1 \mathrm{~m} / \mathrm{sec}$ could be selected. The cylinder velocity was de-

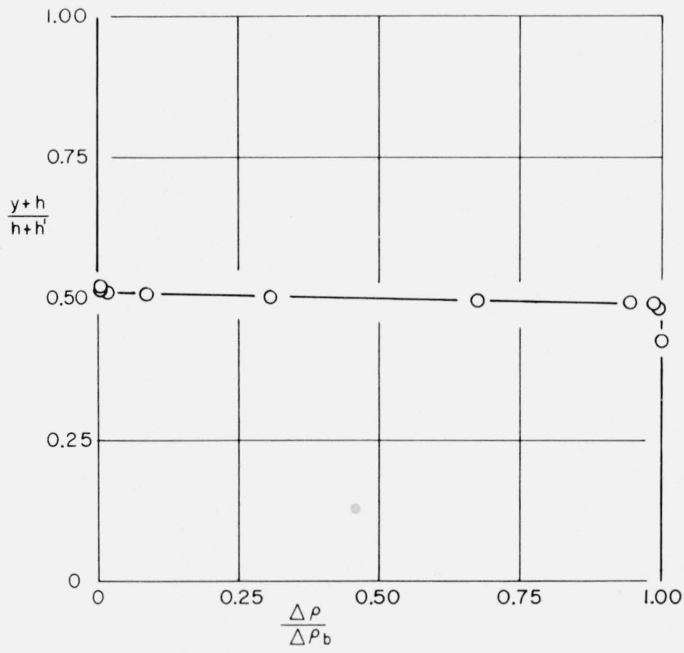

Figure 3. Example of vertical distribution of density.

$y$ is the vertical coordinate with origin at the interface. $\Delta \rho_{b}$ is the difference between the densities at the bottom and at the free surface.
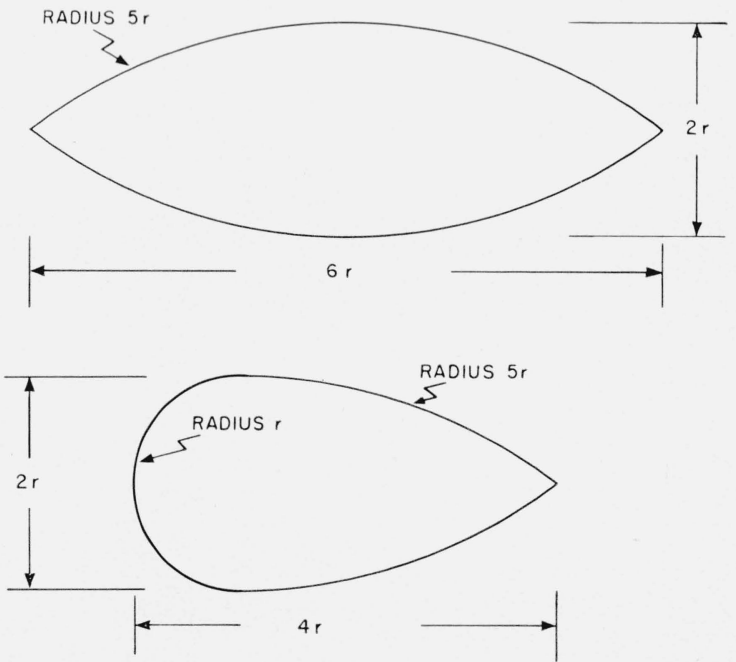

FIGURE 4. Cross sections of lenticular and tear drop cylinders. termined by timing the travel over a distance of $5 \mathrm{~m}$, the first reference mark being $2 \mathrm{~m}$ from the starting position.

The profile of the interface during the run was recorded with three fixed cameras which could be triggered simultaneously or individually. For the majority of the runs, the pictures were taken after the cylinder had traveled about $8 \mathrm{~m}$.

\section{Scope of the Experiments}

In an experimental study relating to the effects of a cylinder when moving in one of the layers of a two-layer system, the items to consider first are the state of rufflement of the interface, the deformation of the free surface, and the particle velocities in the parts far removed from the cylinder. The examination and the measurement of the last two quantities may be omitted in a first study, as these may be inferred from the interface deformation on the basis that the flows are irrotational and the liquids incompressible. A second item would be the additional resistance due to the effect of the internal waves. The observation of this quantity may be omitted, likewise, as it is amenable to a close evaluation from a description of the interface, using for example, the method of Ekman [8].

Accordingly, in the present study only the interface deformation is considered (see fig. 5). The two

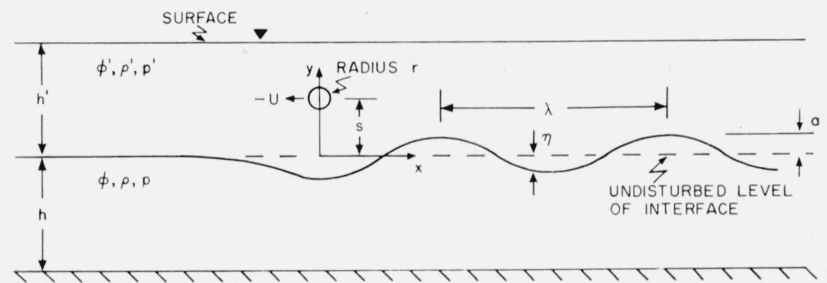

Figure 5. Notation diagram for interfacial disturbance produced by a cylinder moving with constant horizontal velocity in the upper layer.

fundamental quantities to be established were the wave height and wave length in relation to the cylinder speed, cylinder position, the thickness of layers, and the proportionate density difference. It was very surprising to find that the tests in their entirety failed to show a unique type of disturbance. In effect, three modes of deformation could be distinguished. If the layers were nearly of the same thickness, then the interface in most cases yielded a picture of numerous progressive oscillatory waves. If the lower layer was of a smaller thickness than that of the upper, the cylinder was usually followed by an internal solitary wave. On the other hand, if the upper layer was much thinner than the lower, the interface ordinarily deformed into a hydraulic jump.

\section{Internal Oscillatory Progressive Waves}

For those runs of the study for which the salt water and fresh water layers were of equal depth, $h^{\prime}=h$, progressive waves were produced at the 
interface as illustrated in figure 1 . The wavelength, $\lambda$, and the semiwave height, $a$, of the internal waves depend on the following variables:

$U$, velocity of cylinder;

$r$, radius of cylinder;

$h$, depth of saline layer;

$h^{\prime}$, depth of fresh layer;

$\rho$, density of saline layer;

$\rho^{\prime}$, density of fresh layer;

$g$, acceleration of gravity;

$s$, vertical distance of center of cylinder above the undisburbed level of the interface;

$\beta$, shape parameter of cylinder;

$L$, distance traveled by cylinder at time of observation.

Viscous effects are not considered. For the densities used, $\rho^{\prime}=1$ and $1.02 \leq \rho \leq 1.08$, we may write

$$
2 \frac{\rho-\rho^{\prime}}{\rho+\rho^{\prime}}=\frac{\Delta \rho}{\bar{\rho}} \approx \frac{\Delta \rho}{\rho} \text {. }
$$

The values of the variables for the various runs of this class, $h=h^{\prime}$, are given in table 1 . Now

$$
\lambda=\lambda\left(U, r, h, \frac{\Delta \rho}{\rho} g, s, \beta, L\right)
$$

or

$$
\bar{h}=f\left(\frac{U^{2}}{\frac{\Delta \rho}{\rho} g h}, \frac{r}{h}, \frac{s}{h}, \beta, \frac{L}{h}\right) .
$$

In figures 6,7 , and 8 plots are given of $\lambda / h$ against $U^{2} /(\Delta \rho / \rho) g h$, a form of densimetric or internal Froude

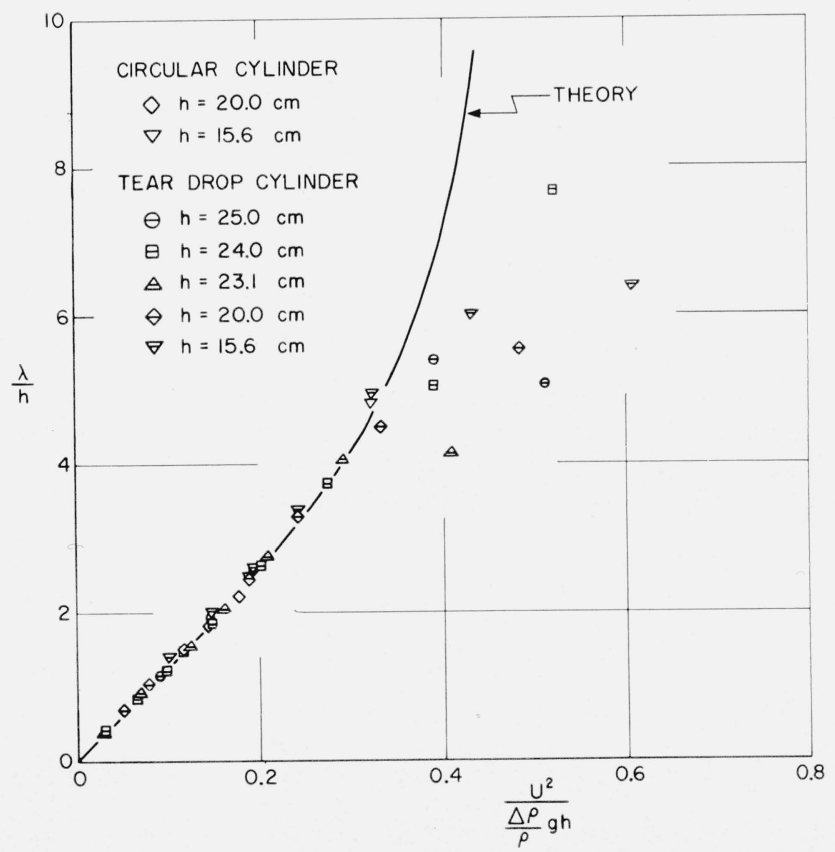

FIgURE 6. Variation of the wavelength of internal progressive waves, $\mathrm{r}=1.27 \mathrm{~cm}$. number. The wavelengths for the experiments were taken as the mean value for three or four waves immediately following the cylinder. The line representing the theoretical wavelength is taken from Lamb, Art. 231 eq (17) [21], which represents wave motion of two superposed fluids with the upper surface free. For the case

$$
\frac{\Lambda \cdot \rho}{\rho} \ll 1
$$

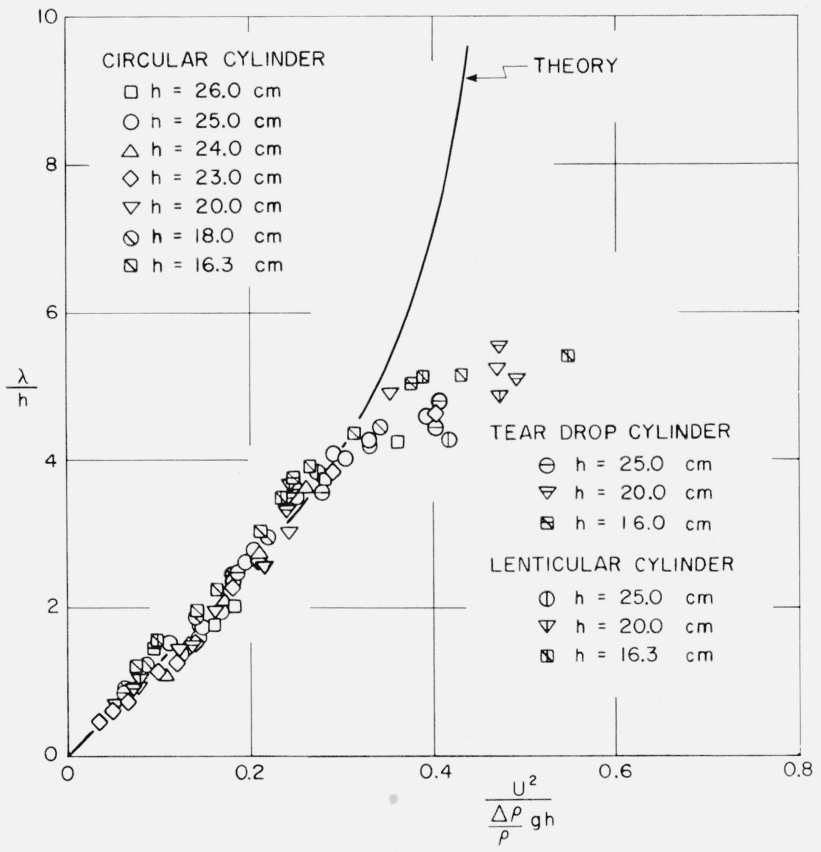

Figure 7. Variation of the wavelength of internal progressive waves, $\mathrm{r}=2.54 \mathrm{~cm}$.

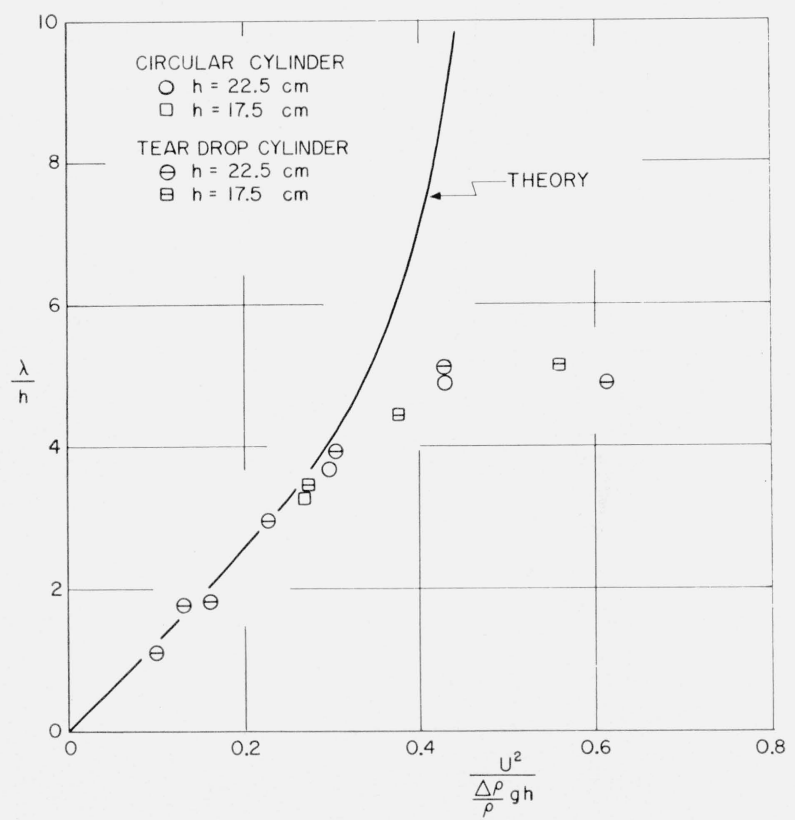

Figure 8. Variation of the wavelength of internal progressive waves, $\mathrm{r}=5.08 \mathrm{~cm}$. 
TABLE 1. Variables for $\mathrm{h}^{\prime}=\mathrm{h}$

\begin{tabular}{|c|c|c|c|c|c|c|c|c|c|c|c|c|c|c|c|}
\hline Run & $\begin{array}{l}\text { Cylin- } \\
\text { der } a\end{array}$ & $h^{\prime}=h$ & 8 & $\frac{\Delta \rho}{\rho}$ & $U$ & $a$ & $\lambda$ & Run & $\begin{array}{l}\text { Cylin- } \\
\text { der a }\end{array}$ & $h^{\prime}=h$ & 8 & $\frac{\Delta o}{\rho}$ & $U$ & $a$ & $\lambda$ \\
\hline $\begin{array}{r}1 \\
2 \\
4 \\
5 \\
10\end{array}$ & $\begin{array}{l}2.54 \mathrm{~A} \\
2.54 \\
2.54 \\
2.54 \\
2.54\end{array}$ & $\begin{array}{l}c m \\
25 \\
25 \\
25 \\
25 \\
25\end{array}$ & $\begin{array}{l}c m \\
5 \\
5 \\
5 \\
5 \\
5\end{array}$ & $\begin{array}{r}0.02 \\
.02 \\
.02 \\
.02 \\
.02\end{array}$ & $\begin{array}{r}\mathrm{cm} / \mathrm{sec} \\
8.4 \\
12.1 \\
15.0 \\
4.0 \\
9.1\end{array}$ & $\begin{array}{r}c m \\
3.9 \\
5.3 \\
2.5 \\
1.2 \\
3.6\end{array}$ & $\begin{array}{r}c m \\
40.0 \\
101.0 \\
10.5 \\
48.5\end{array}$ & $\begin{array}{l}158 \\
160 \\
161 \\
162 \\
163\end{array}$ & $\begin{array}{l}2.54 \\
2.54 \mathrm{C} \\
2.54 \\
2.54 \\
2.54\end{array}$ & $\begin{array}{l}c m \\
20 \\
16.25 \\
16.25 \\
16.25 \\
16.25\end{array}$ & $\begin{array}{l}c m \\
10 \\
13.75 \\
13.75 \\
13.75 \\
13.75\end{array}$ & $\begin{array}{l}.04 \\
.04 \\
.04 \\
.04 \\
.04\end{array}$ & $\begin{array}{r}c m / s e c \\
19.3 \\
8.0 \\
12.3 \\
15.8 \\
18.7\end{array}$ & $\begin{array}{r}c m \\
2.1 \\
0.9 \\
5.8 \\
4.2 \\
1.8\end{array}$ & $\begin{array}{r}c m \\
97.5 \\
25.6 \\
57.0 \\
83.5 \\
88.0\end{array}$ \\
\hline $\begin{array}{l}11 \\
12 \\
15 \\
16 \\
17\end{array}$ & $\begin{array}{l}2.54 \\
2.54 \\
2.54 \\
2.54 \\
2.54\end{array}$ & $\begin{array}{l}25 \\
25 \\
25 \\
25 \\
25\end{array}$ & $\begin{array}{l}5 \\
5 \\
5 \\
5 \\
5\end{array}$ & $\begin{array}{l}.02 \\
.02 \\
.04 \\
.04 \\
.04\end{array}$ & $\begin{array}{l}10.0 \\
13.9 \\
12.0 \\
13.8 \\
15.7\end{array}$ & $\begin{array}{l}4.0 \\
2.3 \\
3.5 \\
4.3 \\
4.7\end{array}$ & $\begin{array}{r}70.0 \\
115.0 \\
43.5 \\
65.5 \\
87.5\end{array}$ & $\begin{array}{l}170 \\
171 \\
172 \\
173 \\
174\end{array}$ & $\begin{array}{l}\text { 5. } 08 \mathrm{~A} \\
5.08 \\
5.08 \\
5.08 \\
5.08\end{array}$ & $\begin{array}{l}17.54 \\
17.54 \\
17.54 \\
17.54 \\
22.46\end{array}$ & $\begin{array}{r}12.46 \\
12.75 \\
12.75 \\
12.75 \\
7.54\end{array}$ & $\begin{array}{l}.04 \\
.04 \\
.04 \\
.04 \\
.04\end{array}$ & $\begin{array}{l}14.0 \\
16.0 \\
19.5 \\
22.8 \\
16.2\end{array}$ & $\begin{array}{l}7.3 \\
6.0 \\
4.5 \\
5.2 \\
9.0\end{array}$ & \begin{tabular}{c}
$\cdots$ \\
$\cdots 3.0$ \\
\hdashline
\end{tabular} \\
\hline $\begin{array}{l}18 \\
19 \\
21 \\
22 \\
23\end{array}$ & $\begin{array}{l}2.54 \\
2.54 \\
2.54 \\
2.54 \\
2.54\end{array}$ & $\begin{array}{l}25 \\
25 \\
25 \\
25 \\
25\end{array}$ & $\begin{array}{l}5 \\
5 \\
5 \\
5 \\
5\end{array}$ & $\begin{array}{l}.04 \\
.04 \\
.08 \\
.08 \\
.08\end{array}$ & $\begin{array}{l}18.0 \\
21.3 \\
16.9 \\
18.9 \\
23.9\end{array}$ & $\begin{array}{l}5.2 \\
2.2 \\
4.3 \\
3.5 \\
5.1\end{array}$ & $\begin{array}{r}44.3 \\
59.5 \\
102.5\end{array}$ & $\begin{array}{l}175 \\
176 \\
178 \\
183 \\
184\end{array}$ & $\begin{array}{l}5.08 \\
5.08 \\
5.08 \\
5.08 \mathrm{~B} \\
5.08\end{array}$ & $\begin{array}{l}22.46 \\
22.46 \\
17.54 \\
22.46 \\
22.46\end{array}$ & $\begin{array}{r}7.54 \\
7.54 \\
12.46 \\
7.54 \\
7.54\end{array}$ & $\begin{array}{l}.04 \\
.04 \\
.04 \\
.04 \\
.04\end{array}$ & $\begin{array}{l}19.5 \\
22.4 \\
13.6 \\
11.9 \\
10.8\end{array}$ & $\begin{array}{r}3.5 \\
3.5 \\
4.9\end{array}$ & $\begin{array}{r}110.0 \\
57.5 \\
41.0 \\
40.0\end{array}$ \\
\hline $\begin{array}{l}24 \\
25 \\
71 \\
72 \\
75\end{array}$ & $\begin{array}{l}2.54 \\
2.54 \\
2.54 \\
2.54 \\
2.54\end{array}$ & $\begin{array}{l}25 \\
25 \\
26 \\
26 \\
26\end{array}$ & $\begin{array}{l}5 \\
5 \\
4 \\
4 \\
4\end{array}$ & $\begin{array}{l}.08 \\
.08 \\
.04 \\
.04 \\
.04\end{array}$ & $\begin{array}{l}22.2 \\
27.6 \\
13.7 \\
19.2 \\
12.8\end{array}$ & $\begin{array}{l}5.0 \\
2.2 \\
4.4 \\
3.3 \\
4.2\end{array}$ & $\begin{array}{r}99.5 \\
52.7 \\
111.0 \\
46.3\end{array}$ & $\begin{array}{l}185 \\
186 \\
187 \\
188 \\
189\end{array}$ & $\begin{array}{l}5.08 \\
5.08 \\
5.08 \\
5.08 \\
5.08\end{array}$ & $\begin{array}{l}22.46 \\
22.46 \\
22.46 \\
22.46 \\
22.46\end{array}$ & $\begin{array}{l}7.54 \\
7.54 \\
7.54 \\
7.54 \\
7.54\end{array}$ & $\begin{array}{l}.04 \\
.04 \\
.04 \\
.04 \\
.04\end{array}$ & $\begin{array}{r}9.4 \\
14.2 \\
16.4 \\
19.5 \\
23.3\end{array}$ & $\begin{array}{l}\text { 3. } 3 \\
6.3 \\
8.3 \\
4.5 \\
2.2\end{array}$ & $\begin{array}{r}25.0 \\
67.0 \\
89.0 \\
1150 \\
110.0\end{array}$ \\
\hline $\begin{array}{l}76 \\
77 \\
78 \\
79 \\
80\end{array}$ & $\begin{array}{l}2.54 \\
2.54 \\
2.54 \\
2.54 \\
2.54\end{array}$ & $\begin{array}{l}26 \\
26 \\
24 \\
24 \\
24\end{array}$ & $\begin{array}{l}4 \\
4 \\
6 \\
6 \\
6\end{array}$ & $\begin{array}{l}.04 \\
.04 \\
.04 \\
.04 \\
.04\end{array}$ & $\begin{array}{l}17.0 \\
22.7 \\
12.8 \\
10.2 \\
11.3\end{array}$ & $\begin{array}{l}4.5 \\
1.3 \\
3.9 \\
3.3 \\
3.5\end{array}$ & $\begin{array}{r}97.5 \\
50.6 \\
26.2 \\
36.3\end{array}$ & $\begin{array}{l}196 \\
197 \\
198 \\
210 \\
211\end{array}$ & $\begin{array}{l}5.08 \\
5.08 \\
5.08 \\
1.27 \mathrm{~B} \\
1.27\end{array}$ & $\begin{array}{l}17.54 \\
17.54 \\
17.54 \\
25 \\
25\end{array}$ & $\begin{array}{l}12.46 \\
12.46 \\
12.46 \\
5 \\
5\end{array}$ & $\begin{array}{l}.04 \\
.04 \\
.04 \\
.04 \\
.04\end{array}$ & $\begin{array}{r}13.7 \\
16.1 \\
19.6 \\
8.0 \\
5.3\end{array}$ & $\begin{array}{l}1.2 \\
0.5\end{array}$ & $\begin{array}{l}61.0 \\
78.0 \\
90.0 \\
21.6 \\
11.3\end{array}$ \\
\hline $\begin{array}{l}81 \\
82 \\
83 \\
85 \\
86\end{array}$ & $\begin{array}{l}2.54 \mathrm{~A} \\
2.54 \\
\text { 2. } 54 \\
\text { 2. } 54 \\
\text { 2. } 54\end{array}$ & $\begin{array}{l}24 \\
24 \\
24 \\
23 \\
23\end{array}$ & $\begin{array}{l}6 \\
6 \\
6 \\
7 \\
7\end{array}$ & $\begin{array}{l}.04 \\
.04 \\
.04 \\
.04 \\
.04\end{array}$ & $\begin{array}{l}14.1 \\
15.7 \\
19.5 \\
10.4 \\
11.3\end{array}$ & $\begin{array}{l}4.1 \\
5.0 \\
2.5 \\
2.8 \\
3.3\end{array}$ & $\begin{array}{r}66.1 \\
87.5 \\
107.0 \\
29.3 \\
36.0\end{array}$ & $\begin{array}{l}212 \\
213 \\
214 \\
215 \\
216\end{array}$ & $\begin{array}{l}1.27 \\
1.27 \\
1.27 \\
1.27 \mathrm{~B} \\
1.27\end{array}$ & $\begin{array}{l}25 \\
25 \\
25 \\
25 \\
25\end{array}$ & $\begin{array}{l}5 \\
5 \\
5 \\
5 \\
5\end{array}$ & $\begin{array}{l}.04 \\
.04 \\
.04 \\
.04 \\
.04\end{array}$ & $\begin{array}{r}9.5 \\
10.7 \\
12.0 \\
13.8 \\
16.3\end{array}$ & $\begin{array}{l}1.5 \\
1.6 \\
1.6 \\
1.8 \\
2.0\end{array}$ & $\begin{array}{l}29.2 \\
38.2 \\
48.8 \\
64.5\end{array}$ \\
\hline $\begin{array}{l}87 \\
88 \\
89 \\
90 \\
91\end{array}$ & $\begin{array}{l}2.54 \\
2.54 \\
2.54 \\
2.54 \\
2.54\end{array}$ & $\begin{array}{l}23 \\
23 \\
23 \\
23 \\
23\end{array}$ & $\begin{array}{l}7 \\
7 \\
7 \\
7 \\
7\end{array}$ & $\begin{array}{l}.04 \\
.04 \\
.04 \\
.04 \\
.04\end{array}$ & $\begin{array}{l}12.8 \\
13.8 \\
16.2 \\
19.1 \\
21.6\end{array}$ & $\begin{array}{l}3.8 \\
3.8 \\
4.8 \\
2.8 \\
1.4\end{array}$ & $\begin{array}{r}53.0 \\
61.3 \\
89.0 \\
107.0 \\
\end{array}$ & $\begin{array}{l}217 \\
218 \\
219 \\
220 \\
221\end{array}$ & $\begin{array}{l}1.27 \\
1.27 \\
1.27 \\
1.27 \\
1.27\end{array}$ & $\begin{array}{l}25 \\
25 \\
23.12 \\
23.12 \\
23.12\end{array}$ & $\begin{array}{l}5 \\
5 \\
6.88 \\
6.98 \\
6.88\end{array}$ & $\begin{array}{l}.04 \\
.04 \\
.04 \\
.04 \\
.04\end{array}$ & $\begin{array}{r}19.6 \\
22.4 \\
5.2 \\
8.0 \\
9.5\end{array}$ & $\begin{array}{l}1.7 \\
0.9 \\
0.1 \\
0.8 \\
1.2\end{array}$ & $\begin{array}{r}135.0 \\
127.0 \\
10.0 \\
21.3 \\
29.5\end{array}$ \\
\hline $\begin{array}{l}92 \\
93 \\
94 \\
95 \\
96\end{array}$ & $\begin{array}{l}2.54 \\
2.54 \\
2.54 \\
2.54 \\
2.54\end{array}$ & $\begin{array}{l}23 \\
23 \\
23 \\
23 \\
20\end{array}$ & $\begin{array}{r}7 \\
7 \\
7 \\
7 \\
10\end{array}$ & $\begin{array}{l}.04 \\
.04 \\
.04 \\
.04 \\
.04\end{array}$ & $\begin{array}{l}9.5 \\
5.7 \\
6.7 \\
7.8 \\
6.4\end{array}$ & $\begin{array}{l}1.8 \\
0.4 \\
1.2 \\
1.7 \\
0.6\end{array}$ & $\begin{array}{l}26.4 \\
11.1 \\
14.8 \\
16.7 \\
14.4\end{array}$ & $\begin{array}{l}222 \\
223 \\
224 \\
225 \\
226\end{array}$ & $\begin{array}{l}1.27 \\
1.27 \\
1.27 \\
1.27 \\
1.27\end{array}$ & $\begin{array}{l}23.12 \\
23.12 \\
23.12 \\
23.12 \\
23.12\end{array}$ & $\begin{array}{l}6.88 \\
6.88 \\
6.88 \\
6.88 \\
6.88\end{array}$ & $\begin{array}{l}.04 \\
.04 \\
.04 \\
.04 \\
.04\end{array}$ & $\begin{array}{l}10.6 \\
12.1 \\
13.8 \\
16.3 \\
19.3\end{array}$ & $\begin{array}{l}1.3 \\
1.5 \\
1.6 \\
2.3 \\
1.5\end{array}$ & $\begin{array}{r}36.0 \\
47.3 \\
64.0 \\
94.0 \\
146.5\end{array}$ \\
\hline $\begin{array}{r}97 \\
98 \\
99 \\
100 \\
101\end{array}$ & $\begin{array}{l}2.54 \\
2.54 \\
2.54 \\
2.54 \\
2.54\end{array}$ & $\begin{array}{l}20 \\
20 \\
20 \\
20 \\
20\end{array}$ & $\begin{array}{l}10 \\
10 \\
10 \\
10 \\
10\end{array}$ & $\begin{array}{l}.04 \\
.04 \\
.04 \\
.04 \\
.04\end{array}$ & $\begin{array}{r}7.7 \\
9.8 \\
11.3 \\
13.0 \\
13.8\end{array}$ & $\begin{array}{l}1.1 \\
2.1 \\
2.7 \\
3.4 \\
3.8\end{array}$ & $\begin{array}{l}19.8 \\
28.8 \\
39.3 \\
52.0 \\
61.0\end{array}$ & $\begin{array}{l}227 \\
228 \\
229 \\
230 \\
231\end{array}$ & $\begin{array}{l}1.27 \\
1.27 \\
1.27 \\
1.27 \\
1.27\end{array}$ & $\begin{array}{l}23.12 \\
24 \\
24 \\
24 \\
24\end{array}$ & $\begin{array}{l}6.88 \\
6 \\
6 \\
6 \\
6\end{array}$ & $\begin{array}{l}.04 \\
.04 \\
.04 \\
.04 \\
.04\end{array}$ & $\begin{array}{r}21.5 \\
5.3 \\
7.8 \\
9.6 \\
10.5\end{array}$ & $\begin{array}{l}0.9 \\
0.2 \\
0.9 \\
1.3 \\
1.5\end{array}$ & $\begin{array}{l}10.4 \\
19.8 \\
29.3 \\
35.1\end{array}$ \\
\hline $\begin{array}{l}102 \\
103 \\
104 \\
105 \\
106\end{array}$ & $\begin{array}{l}2.54 \\
2.54 \\
2.54 \\
2.54 \\
2.54\end{array}$ & $\begin{array}{l}20 \\
20 \\
18 \\
18 \\
18\end{array}$ & $\begin{array}{l}10 \\
10 \\
12 \\
12 \\
12\end{array}$ & $\begin{array}{l}.04 \\
.04 \\
.04 \\
.04 \\
.04\end{array}$ & $\begin{array}{r}16.7 \\
19.2 \\
6.7 \\
7.8 \\
10.0\end{array}$ & $\begin{array}{l}4.0 \\
2.2 \\
0.5 \\
1.0 \\
1.8\end{array}$ & $\begin{array}{r}98.7 \\
105.0 \\
16.6 \\
22.2 \\
33.8\end{array}$ & $\begin{array}{l}232 \\
233 \\
234 \\
235 \\
236\end{array}$ & $\begin{array}{l}1.27 \\
1.27 \\
1.27 \\
1.27 \\
1.27\end{array}$ & $\begin{array}{l}24 \\
24 \\
24 \\
24 \\
24\end{array}$ & $\begin{array}{l}6 \\
6 \\
6 \\
6 \\
6\end{array}$ & $\begin{array}{l}.04 \\
.04 \\
.04 \\
.04 \\
.04\end{array}$ & $\begin{array}{l}11.8 \\
13.8 \\
16.1 \\
19.2 \\
22.2\end{array}$ & $\begin{array}{l}1.5 \\
1.8 \\
2.0 \\
1.9 \\
0.8\end{array}$ & $\begin{array}{r}45.0 \\
63.0 \\
90.5 \\
146.0 \\
162.5\end{array}$ \\
\hline $\begin{array}{l}107 \\
108 \\
109 \\
110 \\
112\end{array}$ & $\begin{array}{l}2.54 \\
2.54 \mathrm{~A} \\
2.54 \\
2.54 \\
2.54\end{array}$ & $\begin{array}{l}18 \\
18 \\
18 \\
18 \\
16.25\end{array}$ & $\begin{array}{l}12 \\
12 \\
12 \\
12 \\
13.75\end{array}$ & $\begin{array}{l}.04 \\
.04 \\
.04 \\
.04 \\
.04\end{array}$ & $\begin{array}{r}11.4 \\
12.4 \\
14.1 \\
15.6 \\
7.0\end{array}$ & $\begin{array}{l}2.7 \\
3.2 \\
3.4 \\
3.8 \\
0.7\end{array}$ & $\begin{array}{l}44.6 \\
53.5 \\
68.3 \\
80.5 \\
19.8\end{array}$ & $\begin{array}{l}237 \\
238 \\
239 \\
240 \\
241\end{array}$ & $\begin{array}{l}1.27 \\
1.27 \\
1.27 \\
1.27 \\
1.27\end{array}$ & $\begin{array}{l}20 \\
20 \\
20 \\
20 \\
20\end{array}$ & $\begin{array}{l}10 \\
10 \\
10 \\
10 \\
10\end{array}$ & $\begin{array}{l}.04 \\
.04 \\
.04 \\
.04 \\
.04\end{array}$ & $\begin{array}{r}6.3 \\
7.9 \\
9.5 \\
10.7 \\
12.2\end{array}$ & $\begin{array}{l}0.2 \\
0.4 \\
0.8 \\
1.0 \\
1.2\end{array}$ & $\begin{array}{l}14.0 \\
20.9 \\
30.5 \\
37.7 \\
49.2\end{array}$ \\
\hline $\begin{array}{l}113 \\
114 \\
115 \\
116 \\
117\end{array}$ & $\begin{array}{l}2.54 \\
2.54 \\
2.54 \\
2.54 \\
2.54\end{array}$ & $\begin{array}{l}16.25 \\
16.25 \\
16.25 \\
16.25 \\
16.25\end{array}$ & $\begin{array}{l}13.75 \\
13.75 \\
13.75 \\
13.75 \\
13.75\end{array}$ & $\begin{array}{l}.04 \\
.04 \\
.04 \\
.04 \\
.04\end{array}$ & $\begin{array}{r}9.5 \\
10.3 \\
11.6 \\
13.0 \\
14.2\end{array}$ & $\begin{array}{l}2.8 \\
3.2 \\
5.2 \\
6.4 \\
6.3\end{array}$ & $\begin{array}{l}32.2 \\
37.0 \\
49.4 \\
63.7 \\
71.3\end{array}$ & $\begin{array}{l}242 \\
243 \\
244 \\
245 \\
246\end{array}$ & $\begin{array}{l}\text { 1. } 27 \mathrm{~B} \\
\text { 1. } 27 \\
\text { 1. } 27 \\
\text { 1. } 27 \\
\text { 1. } 27\end{array}$ & $\begin{array}{l}20 \\
20 \\
20 \\
15.635 \\
15.635\end{array}$ & $\begin{array}{l}10 \\
10 \\
10 \\
14.365 \\
14.365\end{array}$ & $\begin{array}{l}.04 \\
.04 \\
.04 \\
.04 \\
.04\end{array}$ & $\begin{array}{r}13.8 \\
16.2 \\
19.5 \\
6.2 \\
7.9\end{array}$ & $\begin{array}{l}1.5 \\
2.3 \\
1.0 \\
0.1 \\
0.2\end{array}$ & $\begin{array}{r}66.0 \\
90.2 \\
160.5\end{array}$ \\
\hline $\begin{array}{l}118 \\
142 \\
143 \\
144 \\
145\end{array}$ & $\begin{array}{l}2.54 \\
2.54 \mathrm{~B} \\
2.54 \\
2.54 \\
2.54\end{array}$ & $\begin{array}{l}16.25 \\
25 \\
25 \\
25 \\
20\end{array}$ & $\begin{array}{c}13.75 \\
5 \\
5 \\
5 \\
10\end{array}$ & $\begin{array}{l}.04 \\
.04 \\
.04 \\
.04 \\
.04\end{array}$ & $\begin{array}{r}16.6 \\
11.1 \\
16.6 \\
20.0 \\
7.7\end{array}$ & $\begin{array}{l}4.1 \\
3.4 \\
5.7 \\
3.2 \\
1.0\end{array}$ & $\begin{array}{r}84.0 \\
35.5 \\
89.3 \\
120.0 \\
19.2\end{array}$ & $\begin{array}{l}247 \\
248 \\
249 \\
250 \\
251\end{array}$ & $\begin{array}{l}1.27 \\
1.27 \\
1.27 \\
1.27 \\
1.27\end{array}$ & $\begin{array}{l}15.635 \\
15.635 \\
15.635 \\
15.635 \\
15.635\end{array}$ & $\begin{array}{l}\text { 14. } 365 \\
\text { 14. } 365 \\
\text { 14. } 365 \\
\text { 14. } 365 \\
\text { 14. } 365\end{array}$ & $\begin{array}{l}.04 \\
.04 \\
.04 \\
.04 \\
.04\end{array}$ & $\begin{array}{r}9.6 \\
10.9 \\
12.2 \\
14.1 \\
16.3\end{array}$ & $\begin{array}{l}0.8 \\
1.3 \\
1.9 \\
3.3 \\
2.0\end{array}$ & $\begin{array}{r}31.6 \\
41.0 \\
53.0 \\
77.5 \\
126.0\end{array}$ \\
\hline $\begin{array}{l}146 \\
147 \\
148 \\
149 \\
150\end{array}$ & $\begin{array}{l}2.54 \\
2.54 \\
2.54 \\
2.54 \\
2.54\end{array}$ & $\begin{array}{l}20 \\
20 \\
16.25 \\
16.25 \\
16.25\end{array}$ & $\begin{array}{l}10 \\
10 \\
13.75 \\
13.75 \\
13.75\end{array}$ & $\begin{array}{l}.04 \\
.04 \\
.04 \\
.04 \\
.04\end{array}$ & $\begin{array}{r}13.7 \\
19.7 \\
7.8 \\
12.6 \\
15.5\end{array}$ & $\begin{array}{l}4.5 \\
1.7 \\
1.0 \\
4.6 \\
4.7\end{array}$ & $\begin{array}{r}66.7 \\
102.0 \\
24.0 \\
61.5 \\
82.2\end{array}$ & $\begin{array}{l}252 \\
275 \\
276 \\
277\end{array}$ & $\begin{array}{l}\text { 1. } 27 \\
\text { 1. } 27 \mathrm{~A} \\
\text { 1. } 27 \\
\text { 1. } 27\end{array}$ & $\begin{array}{l}15.635 \\
20 \\
15.635 \\
15.635\end{array}$ & $\begin{array}{l}14.365 \\
10 \\
14.365 \\
14.365\end{array}$ & $\begin{array}{l}.04 \\
.04 \\
.04 \\
.04\end{array}$ & $\begin{array}{l}19.3 \\
11.8 \\
10.8 \\
14.1\end{array}$ & $\begin{array}{l}\text { 1. } 0 \\
\text { 1. } 0 \\
\text { 1. } 2 \\
\text { 3. }\end{array}$ & $\begin{array}{r}138.4 \\
45.0 \\
39.0 \\
75.5\end{array}$ \\
\hline $\begin{array}{l}153 \\
154 \\
155 \\
156 \\
157\end{array}$ & $\begin{array}{l}2.54 \mathrm{C} \\
2.54 \\
2.54 \\
2.54 \\
2.54\end{array}$ & $\begin{array}{l}25 \\
25 \\
25 \\
20 \\
20\end{array}$ & $\begin{array}{r}5 \\
5 \\
5 \\
10 \\
10\end{array}$ & $\begin{array}{l}.04 \\
.04 \\
.04 \\
.04 \\
.04\end{array}$ & $\begin{array}{r}11.1 \\
16.4 \\
20.2 \\
7.9 \\
13.9\end{array}$ & $\begin{array}{l}3.5 \\
4.2 \\
2.7 \\
0.8 \\
3.8\end{array}$ & $\begin{array}{r}34.8 \\
96.0 \\
107.0 \\
21.1 \\
73.7\end{array}$ & & aders & $\begin{array}{l}\text { bulat } \\
\text { cular. }\end{array}$ & y radit & enti & ters) an & shape & circular \\
\hline
\end{tabular}


in which we are interested the equation may be written

$$
\sigma^{4} \rho N_{1}-\sigma^{2} \rho g k N_{2}+\Delta \rho g^{2} k^{2}=0
$$

where

$$
\begin{aligned}
N_{1} & =\operatorname{coth} k h \operatorname{coth} k h^{\prime}+1 \\
N_{2} & =\operatorname{coth} k h+\operatorname{coth} k h^{\prime} \\
k & =2 \pi / \lambda \\
\sigma & =k U .
\end{aligned}
$$

The equation reduces to

$$
\frac{U^{2}}{\frac{\Delta \rho}{\rho} g h}=\frac{N_{2}}{2 N_{1} \epsilon k h}\left[1 \pm \sqrt{1-\frac{4 N_{1} \epsilon}{N_{2}{ }^{2}}}\right]
$$

where $\epsilon=\Delta \rho / \rho$. There are two solutions of this equation corresponding to the plus and minus signs for the last term. The minus sign represents the case of interest here where waves are produced primarily at the interface. Since the quantity $N_{1} \epsilon / N_{2}{ }^{2}$ is small, we may expand the square root obtaining.

$$
\frac{U^{2}}{\frac{\Delta \rho}{\rho} g h}=\frac{1}{N_{2} k h}\left[1+\frac{N_{1} \epsilon}{N_{2}{ }^{2}}+\cdots\right] .
$$

For the present experiments $N_{1} \epsilon / N_{2}{ }^{2}<0.03$, so only the first term is taken

$$
\frac{U^{2}}{\frac{\Delta \rho}{\rho} g h}=\frac{1}{2 \pi} \frac{\lambda}{h} \frac{1}{\operatorname{coth} \frac{2 \pi h}{\lambda}+\operatorname{coth} \frac{2 \pi h^{\prime}}{\lambda}} .
$$

This relation is the general expression for wave velocity of a two-layer system. Taking the limit as $\lambda / h \rightarrow \infty$ we obtain

$$
\frac{U_{c}^{2}}{\frac{\Delta \rho}{\rho} g h}=\frac{h^{\prime}}{h+h^{\prime}}
$$

for the velocity of long waves. For the condition of the experiments, $h^{\prime}=h$, we have

$$
\frac{U^{2}}{\frac{\Delta \rho}{\rho} g h}=\frac{1}{4 \pi} \frac{\lambda}{h} \tanh \frac{2 \pi h}{\lambda}
$$

which is the basis of the theoretical curves in figures 6,7 , and 8 . The agreement is good when $U^{2} /(\Delta \rho / \rho) g h$ does not exceed 0.3. For larger values of $U^{2} /$ $(\Delta \rho / \rho) g h$ the wavelength tends to be constant. At the present time no explanation can be given for this result.

For the wave heights, neglecting viscous effects, we have

or

$$
a=a\left(U, r, h, s, \beta, \frac{\Delta \rho}{\rho} g, L\right)
$$

$$
\frac{a}{r}=f\left(\frac{U^{2}}{\frac{\Delta \rho}{\rho} g h}, \frac{U^{2}}{\frac{\Delta \rho}{\rho} g s}, \frac{r}{h}, \beta, \frac{L}{h}\right) .
$$

A plot of $a / r$ against $U^{2} /(\Delta \rho / \rho) g s$ is given in figure 9 . Those points corresponding to cases where the cylinder touches the free surface, $(s+r) / h^{\prime}=1$, would not correlate well with the other points and are plotted separately in figure 10. An explanation for this will appear in the theoretical development where

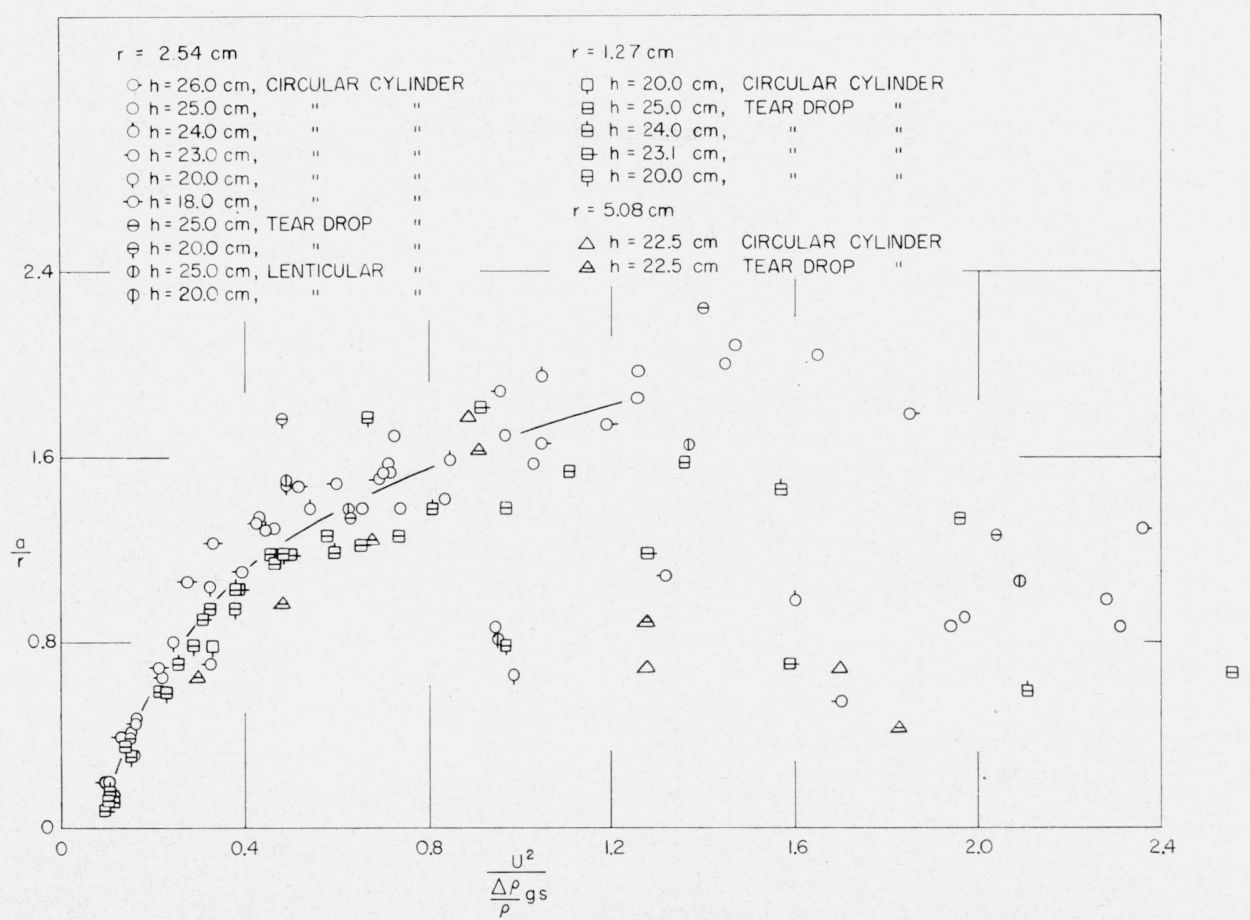

FIGURE 9. Variation of the wave height of internal progressive waves for those cases where the cylinder does not touch the surface. 


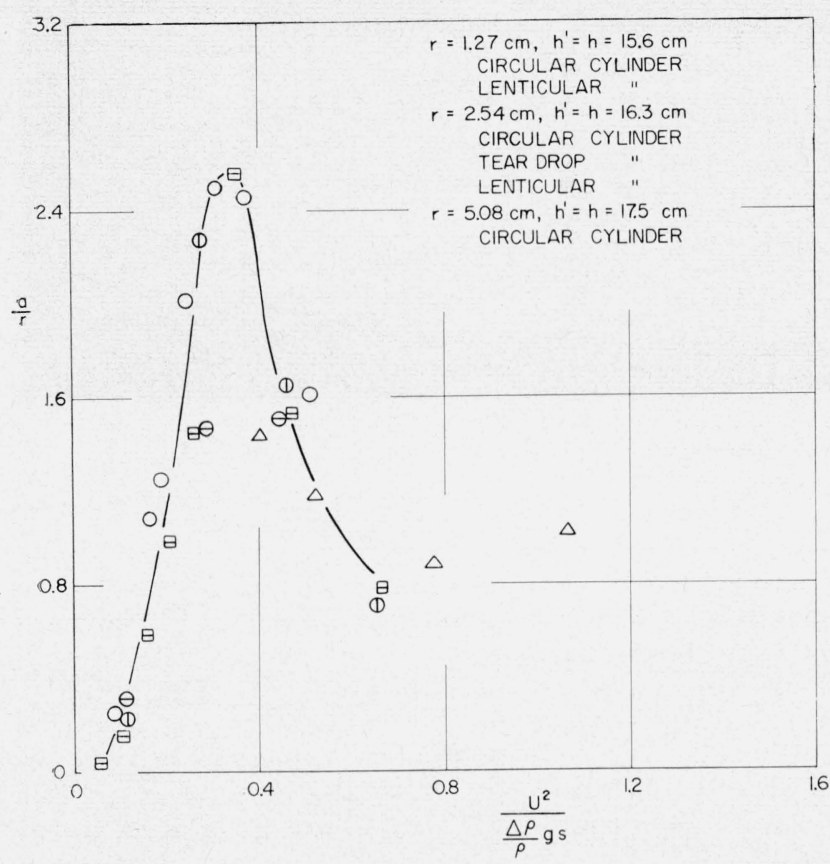

Figure 10. Variation of the wave height of internal progres.ive waves for those cases where the cylinder touches the surface.

successive images of the cylinder in the surface are taken. A plot of $a / r$ against $U^{2} /(\Delta \rho / \rho) g h$ is given in figure 11. The maximum value of $a / r$ occurs at about $U^{2} /(\Delta \rho / \rho) g h=0.3$. Comparing this with the expression for wave velocity $U_{c}$ of long waves it is seen that $U_{m} / U_{c}=0.77$, where $U_{m}$ is the velocity corresponding to maximum wave height. In this respect there appears to be a close agreement with Ekman's results of maximum added resistance, as large wave height reflects the largeness of the added resistance. The data of $a / r$ from runs where the cylinder was not in contact with the surface are plotted against

$$
\frac{U^{2}}{\frac{\Delta \rho}{\rho} g s} \text { for } \frac{U^{2}}{\frac{\Delta \rho}{\rho} g h}<0.3
$$

in figure 12.

From the data on wavelengths and wave heights it would be difficult to distinguish any significant

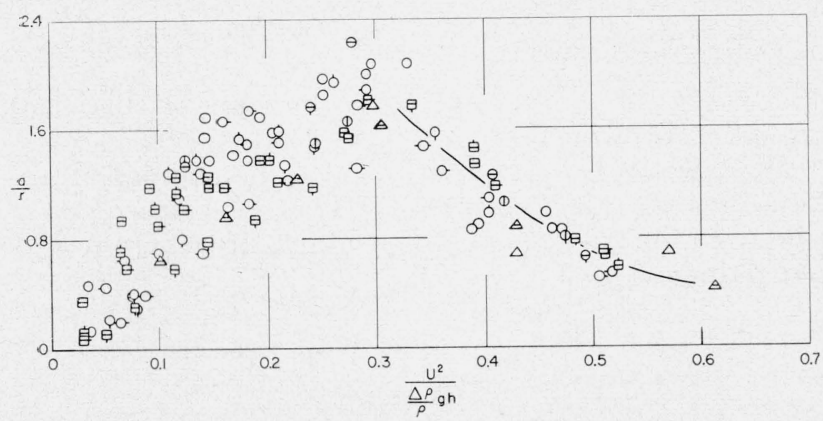

FIGURE 11. Variation of the wave height of internal progressive waves where the cylinder does not touch the surface.

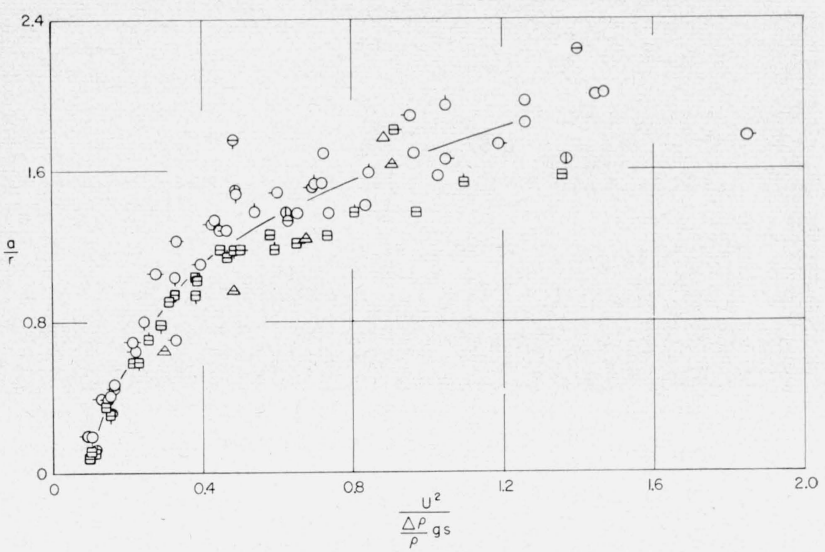

Figure 12. Variation of the wave height of internal progressive waves where the cylinder does not touch the surface for $U^{2} /(\Delta \rho / \rho) g h<0.3$.

difference between the waves produced by the cylinders of various shapes. This may be due to the wake being independent of the cylinder shape, although no observations were made of the wake.

For sufficiently large values of $r / s$ there exists a minimum velocity below which progressive waves are not produced. Instead, there is a vortex formation below the cylinder followed by a smooth undisturbed boundary. It can be seen from figure 12 that the wave height increases as $r / s$ is increased.

For large values of $r / h$ the disturbance assumes the form of an internal hydraulic jump which will be discussed in section 6 .

The effect of the parameter $L / h$ cannot be evaluated at this time since $L$ was nearly constant for all the runs.

\section{Translation Waves of the Bottom Layer}

For those runs for which $h<<h^{\prime}$, translation waves of the form illustrated in figure 13 were formed at the interface. In all the runs of this class the cylinder touches the free surface. If the cylinder were completely below the surface, waves of the same form would be produced. The characteristics of the intumescence are similar to those of internal solitary waves. Letting $a$ be the height of the wave crest above the undisturbed level of the interface, we have, neglecting viscous effects

or

$$
a=a\left(U, r, h, h^{\prime}, s, \beta, \frac{\Delta \rho}{\rho} g, L\right)
$$

$$
\frac{a}{r}=f\left(\frac{U^{2}}{\frac{\Delta \rho}{\rho} g h}, \frac{h^{\prime}}{h}, \frac{s}{h}, \frac{L}{h} \cdot \beta, \frac{r}{h}\right) .
$$

The values of the variables for the runs of this class are given in table 2 .

In figure 14 a plot is given of $a / r$ against $U^{2} /$ $(\Delta \rho / \rho) g h$. Examining the figure, the maximum value of $a / r$ occurs for $U^{2} /(\Delta \rho / \rho) g h=0.52$. Comparing this with the velocity for long waves, eq (a), the ratio 


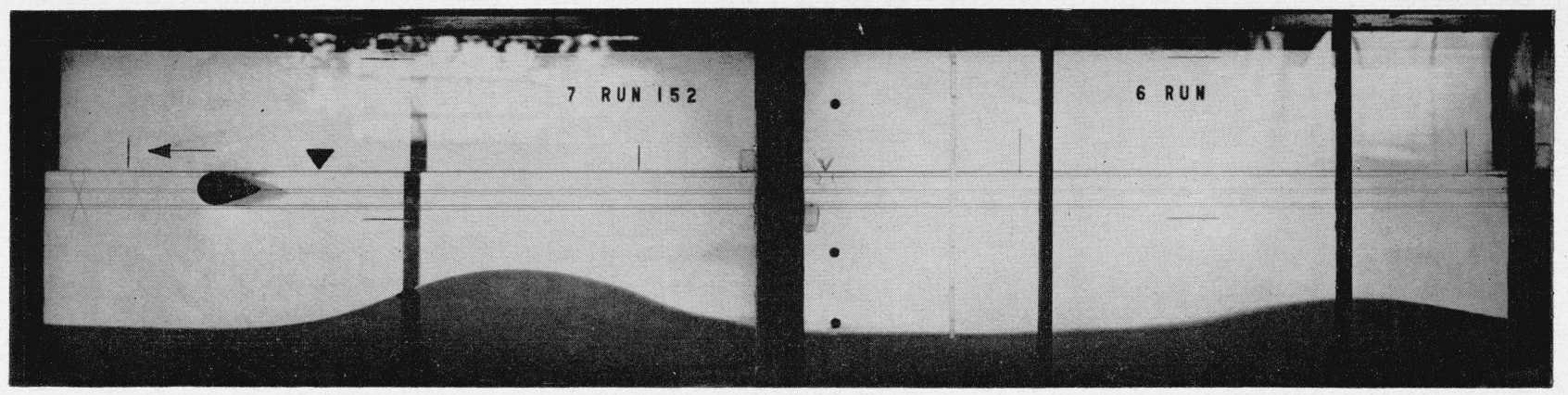

FIGURE 13. Example of translation waves of the bottom layer produced when $\mathrm{h}<<\mathrm{h}^{\prime}$.

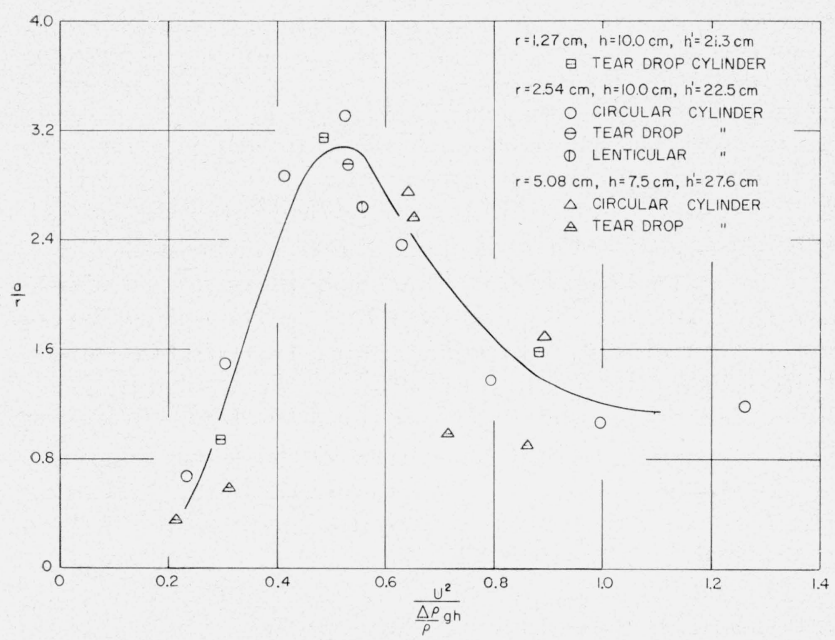

Figure 14. Tariation of the wave height of translation waves of the bottom layer.

TABLE 2. Variables for $\mathrm{h}<<\mathrm{h}^{\prime}$

$\frac{\Delta \rho}{\rho}=0.04$ for all runs

\begin{tabular}{|c|c|c|c|c|c|c|}
\hline Run & Cylinder $a$ & $h^{\prime}$ & $h$ & $s$ & $U$ & $a$ \\
\hline & & $\mathrm{cm}$ & $\mathrm{cm}$ & $\mathrm{cm}$ & $\mathrm{cm} / \mathrm{sec}$ & $\mathrm{cm}$ \\
\hline 131 & 2. $54 \mathrm{~A}$ & 22.5 & 10 & 20 & 9.6 & 1.7 \\
\hline 132 & 2. 54 & 22.5 & 10 & 20 & 11.0 & 3.8 \\
\hline 133 & 2. 54 & 22.5 & 10 & 20 & 12.7 & 7.3 \\
\hline 134 & 2. 54 & 22.5 & 10 & 20 & 14. 3 & 8.4 \\
\hline 135 & 2. 54 & 22.5 & 10 & 20 & 15.7 & 6.0 \\
\hline 139 & 2. 54 & 22.5 & 10 & 20 & 19.8 & 2.7 \\
\hline $\begin{array}{l}109 \\
140\end{array}$ & 2.54 & 22.5 & 10 & 20 & $\begin{array}{l}22.0 \\
22.2\end{array}$ & 3. 0 \\
\hline 141 & 2. 54 & 22.5 & 10 & 20 & 17.7 & 3.5 \\
\hline & 2. $54 \mathrm{~B}$ & 22.5 & 10 & 20 & 14. 4 & 7.5 \\
\hline 164 & $2.54 \mathrm{C}$ & 22.5 & 10 & 20 & 14.8 & 6.7 \\
\hline 180 & $5.08 \mathrm{~A}$ & 27.62 & 7. 46 & 22.54 & 13.7 & 14.0 \\
\hline 181 & 5.08 & 27.62 & 7. 46 & 22.54 & 16. 2 & 8.6 \\
\hline 199 & 5. $08 \mathrm{~B}$ & 27. 62 & 7. 46 & 22.54 & 7.9 & 1.8 \\
\hline $\begin{array}{l}200 \\
201\end{array}$ & $\begin{array}{l}5.08 \\
5.08\end{array}$ & $\begin{array}{l}27.62 \\
27.62\end{array}$ & $\begin{array}{l}7.46 \\
7.46\end{array}$ & $\begin{array}{l}22.54 \\
22.54\end{array}$ & $\begin{array}{r}9.5 \\
10.7\end{array}$ & $\begin{array}{l}3.0 \\
5.0\end{array}$ \\
\hline & & & & & 1 & 130 \\
\hline 208 & $\begin{array}{l}5.08 \\
5.08\end{array}$ & 27.62 & 7.46 & 22.54 & $\begin{array}{l}10.8 \\
15.9\end{array}$ & $\begin{array}{r}1.0 \\
4.6\end{array}$ \\
\hline 278 & 1. $27 \mathrm{~B}$ & 21.27 & 10 & 20 & 10.8 & 1.2 \\
\hline 279 & 1. 27 & 21. 27 & 10 & 20 & 13.8 & 4. 0 \\
\hline 281 & 1. 27 & 21.27 & 10 & 20 & 18.6 & 2.0 \\
\hline
\end{tabular}

${ }^{a}$ Cylinders are tabulated by radius (in centimeters) and by shape; A circular $\mathrm{B}$ tear drop, C lenticular.
$U_{m} / U_{c}$ has the values $0.87,0.87$, and 0.81 corresponding to the cylinders $r=1.27 \mathrm{~cm}, 2.54 \mathrm{~cm}$, and $5.08 \mathrm{~cm}$, respectively.

For the runs of this class, $h<<h^{\prime}$, the cylinder touches the surface so the value of $r / s$ is small in nearly all cases. Thus for low velocities, waves are produced and these are of small wave height. For these cases progressive waves are produced as in section 4. The apparent criterion for transition from progressive waves to translation type waves is the following: For low velocities progressive waves of small amplitude are produced. For larger velocities the amplitudes increase until they become significantly large in comparison to the depth $h$ of the lower layer for the translation type waves to be produced. No effort was made to determine precisely these transition velocities.

\section{Hydraulic Jump of the Upper Layer}

For those runs for which $h^{\prime}<<h$, translation waves of the form illustrated in figure 15 were formed at the interface. Here again the cylinder touches the free surface in all cases. At the start of a run progressive waves are formed. As the cylinder moves on, the waves grow in amplitude and the first crest flattens out because of the proximity of the fresh water surface. Letting $\Lambda$ be the horizontal distance between the center of the cylinder and the first trough, $\Lambda$ increases with the distance of travel $L$. In general, neglecting viscous effects,

$$
\Lambda=\Lambda\left(U, r, h^{\prime}, h, \frac{\Delta \rho}{\rho} g, s, \beta, L\right) .
$$

The values of the variables for the runs of this class are given in table 3.

We wish $\Lambda / L$ as a function of dimensionless combinations of the variables. The best correlation that was obtained is given in figure 16 where $\Lambda / L$ is plotted against

$$
\frac{U^{2}}{\frac{\Delta \rho}{\rho} g h^{\prime}} \sqrt{r / L} .
$$

Here again, as in section 5 , there are cases, for low 


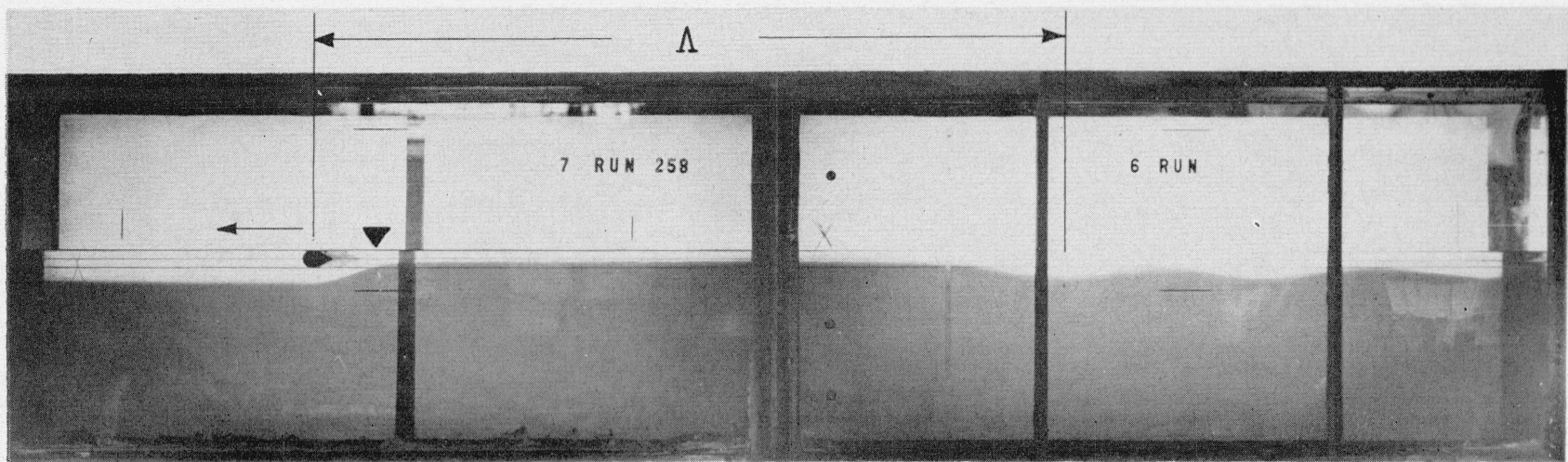

FiguRE 15. Example of internal hydraulic jump of the upper layer produced when $\mathrm{h}^{\prime}<<\mathrm{h}$.

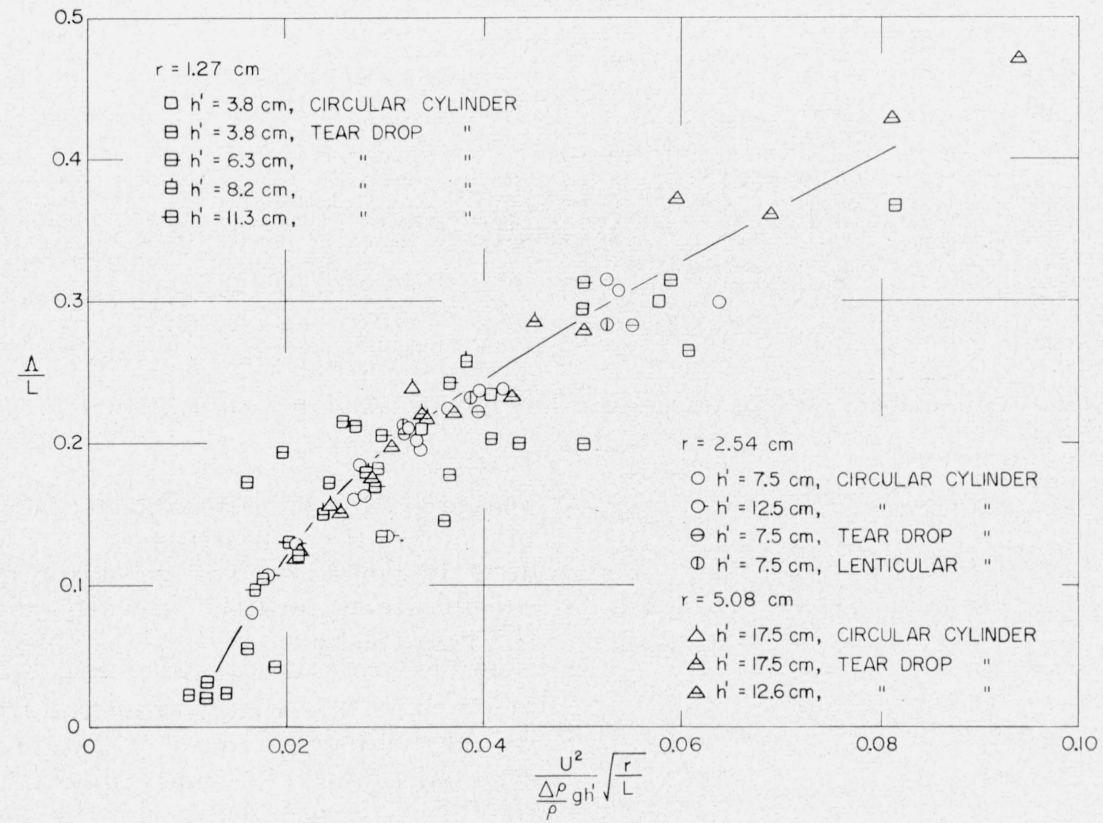

Figure 16. Variation of the length of the "plateau" of translation waves of the upper layer.

velocities where progressive waves are produced at the interface. There are also intermediate cases where the first crest is flattened, but in other respects the profile has the characteristics of a progressive wave train. There are still further cases when $r / h$ is large where the hydraulic jump is produced when the two liquids are of equal depth (runs 178, 196, and 197 listed in table 3).

\section{Theoretical Development}

In order to see to what degree the observed wave heights are in conformity with the laws of hydrodynamics, the case of a cylinder moving with uniform horizontal velocity in the upper layer is considered. This analysis refers to the oscillatory waves of the interface. Corresponding analyses of the translation waves of the bottom and upper layers are being considered.
It will be assumed that $r$ is small compared with the distance $s$ (see fig. 5). Since the speed of motion $U$ is many times smaller than the quantity $\sqrt{g\left(h+h^{\prime}\right)}$ the surface disturbance due to motion of the cylinder as it would be in a homogeneous liquid would be unappreciable, and also owing to small $\Delta \rho / \rho$ ratio the surface displacement associated with internal waves would be negligible. In this case, when the cylinder is near the free surface, it will be necessary to take the successive images of the cylinder in the surface as if it were a plane boundary in order to reduce the normal velocity at the surface to zero. For the present purpose, since $r / s$ is assumed small, all of the image doublets within the cylinder may be placed at the center which effectively increases the radius of the cylinder by a factor $\gamma$. The values of $\gamma$ as a function of $\left(h^{\prime}-s\right) / r$ are determined by the methods of reference [22] and plotted in figure 17 . The sharp rise in $\gamma$ for $\left(h^{\prime}-s\right) / r=L$ accounts for the 
TABLE 3. Variables for $\mathrm{h}^{\prime} \ll \mathrm{h}$

$\frac{\Delta \rho}{\rho}=0.04$ for all runs

\begin{tabular}{|c|c|c|c|c|c|c|c|c|c|c|c|}
\hline Run & $\begin{array}{c}\text { Cylin- } \\
\text { der a }\end{array}$ & $h^{\prime}$ & $h$ & $s$ & $U$ & $\Lambda_{1}$ & $L_{1}$ & $\Lambda_{2}$ & $L_{2}$ & $\Lambda_{3}$ & $L_{3}$ \\
\hline $\begin{array}{l}119 \\
124 \\
125 \\
126 \\
128\end{array}$ & $\begin{array}{l}2.54 \mathrm{~A} \\
2.54 \\
2.54 \\
2.54 \\
2.54\end{array}$ & $\begin{array}{r}c m \\
7.5 \\
12.5 \\
12.5 \\
12.5 \\
7.5\end{array}$ & $\begin{array}{l}c m \\
25 \\
20 \\
20 \\
20 \\
25\end{array}$ & $\begin{array}{r}c m \\
5 \\
10 \\
10 \\
10 \\
5\end{array}$ & $\begin{array}{r}\mathrm{cm} / \mathrm{sec} \\
9.4 \\
12.6 \\
13.7 \\
16.3 \\
10.8\end{array}$ & 91.0 & 517.0 & 96.0 & 557.5 & $\begin{array}{r}c m \\
73.0 \\
94.0 \\
114.0 \\
115.5\end{array}$ & $\begin{array}{l}c m \\
867.5 \\
839.0 \\
892.0 \\
819.0\end{array}$ \\
\hline $\begin{array}{l}129 \\
130\end{array}$ & $\begin{array}{l}\text { 2. } 54 \\
\text { 2. } 54\end{array}$ & $\begin{array}{l}7.5 \\
7.5\end{array}$ & $\begin{array}{l}25 \\
25 \\
25\end{array}$ & $\begin{array}{l}5 \\
5 \\
5\end{array}$ & $\begin{array}{l}12.1 \\
13.2\end{array}$ & $\begin{array}{r}96.0 \\
107.0\end{array}$ & $\begin{array}{l}363.0 \\
309.0\end{array}$ & $\begin{array}{l}121.5 \\
151.8\end{array}$ & $\begin{array}{l}572.0 \\
622.0\end{array}$ & $\begin{array}{l}164.0 \\
187.0\end{array}$ & $\begin{array}{l}851.0 \\
848.0\end{array}$ \\
\hline 136 & 2. 54 & 7.5 & 25 & 5 & 15. 5 & 136.0 & 415.0 & 206. 0 & 613.0 & & \\
\hline $\begin{array}{l}151 \\
159\end{array}$ & $\begin{array}{l}2.54 \mathrm{~B} \\
2.54 \mathrm{C}\end{array}$ & $\begin{array}{l}7.5 \\
7.5\end{array}$ & $\begin{array}{l}25 \\
25\end{array}$ & $\begin{array}{l}5 \\
5\end{array}$ & $\begin{array}{l}13.1 \\
13.1\end{array}$ & $\begin{array}{l}91.5 \\
99.0\end{array}$ & $\begin{array}{l}284.5 \\
310.0\end{array}$ & $\begin{array}{l}131.5 \\
142.0\end{array}$ & $\begin{array}{l}553.0 \\
571.0\end{array}$ & $\begin{array}{l}183.0 \\
186.0\end{array}$ & $\begin{array}{l}846.0 \\
839.0\end{array}$ \\
\hline 178 & $5.08 \mathrm{~A}$ & 17. 54 & 17.54 & 12.46 & 13. 6 & 90.0 & 344.0 & 102.0 & 615.0 & 106. 0 & 834.5 \\
\hline 196 & 5. $08 \mathrm{~B}$ & 17. 54 & 17. 54 & 12.46 & 13. 7 & 82.0 & 331.0 & 94.0 & 582.0 & 111. 0 & 840.0 \\
\hline 197 & 5. 08 & 17. 54 & 17.54 & 12.46 & 16. 1 & 112.0 & 352.0 & 142.0 & 614.5 & 159.0 & 867.5 \\
\hline 203 & 5. $08 \mathrm{~B}$ & 12. 62 & 22.46 & 7. 54 & 14. 0 & 100.0 & 317.5 & 138.0 & 583.0 & 176.0 & 848.0 \\
\hline 204 & 5.08 & 12. 62 & 22.46 & 7.54 & 16. 6 & 131.0 & 332.5 & & & 208.0 & 854.0 \\
\hline 205 & 5. 08 & 12. 62 & 22.46 & 7. 54 & 19.5 & 177.0 & 336.0 & & & 328.0 & 840.0 \\
\hline 206 & & 12.62 & 22.46 & 7.54 & 22.6 & & & & & 370.0 & 824.0 \\
\hline & 1.2 & & 27.5 & 2.5 & 6. 2 & 20.5 & 331.5 & 20.0 & 591.0 & 20.5 & 847.5 \\
\hline & 1.2 & & 27. & 2.5 & 6.7 & 15.5 & 324.0 & 15.5 & 609.5 & 17.5 & 828.5 \\
\hline 256 & 1. 27 & 3. 77 & 27.5 & 2.5 & 7.8 & 78.0 & 322.0 & 115.0 & 551.0 & 152.0 & 841.0 \\
\hline 257 & 1. 27 & 3. 77 & 27.5 & 2. 5 & 9. 6 & 68.0 & 294. 5 & 112.0 & 573.5 & 152. 0 & 837.0 \\
\hline $\begin{array}{l}258 \\
250\end{array}$ & 1. 27 & $\begin{array}{l}3.77 \\
3.77\end{array}$ & $\begin{array}{l}27.5 \\
27.5\end{array}$ & $\begin{array}{r}2.5 \\
2.5\end{array}$ & 10. & 66 & & & & 118 & $\begin{array}{l}840.0 \\
8000\end{array}$ \\
\hline 259 & 1. 27 & 3. 77 & 27.5 & 2. 5 & 11. 8 & 91.0 & $\begin{array}{l}305.0 \\
\end{array}$ & 126.0 & 590.0 & 156.0 & 839.0 \\
\hline $\begin{array}{l}260 \\
263\end{array}$ & 1. 27 & 3. 77 & 27.5 & 2.5 & 13. 8 & 131.0 & $\begin{array}{l}317.5 \\
303\end{array}$ & 204. 0 & $\begin{array}{l}609.0 \\
568\end{array}$ & 259.0 & $\begin{array}{l}840.0 \\
817\end{array}$ \\
\hline 263 & 1. 27 & 6.27 & & 5 & 10.5 & 58.0 & 303.5 & 73.5 & 568.5 & 90.0 & 817.5 \\
\hline 264 & 1. 27 & 6. 27 & 25 & 5 & 13.8 & 107.0 & 302.5 & 148.0 & 571.0 & 186. 0 & 865.0 \\
\hline 269 & 1. 27 & & 23.12 & 6. 88 & & 92 & & 113.0 & & 131.0 & 826.0 \\
\hline 272 & 1. 27 & 11. 27 & 20 & 10 & 13. 8 & $\begin{array}{r}77.5 \\
\end{array}$ & $\begin{array}{l}324.5 \\
\end{array}$ & $\begin{array}{r}80.5 \\
\end{array}$ & $\begin{array}{r}575.0 \\
-500\end{array}$ & $\begin{array}{r}84.0 \\
\end{array}$ & $\begin{array}{l}829.5 \\
85 .\end{array}$ \\
\hline 274 & $1.27 \mathrm{~A}$ & 3. 77 & 27.5 & 2.5 & 11.4 & 100.2 & 294. 3 & 147.5 & 590.2 & 188.5 & 857.5 \\
\hline
\end{tabular}

a Cylinders are tabulated by radius (in centimeters) and by shape; A circular, B tear drop, C lenticular.

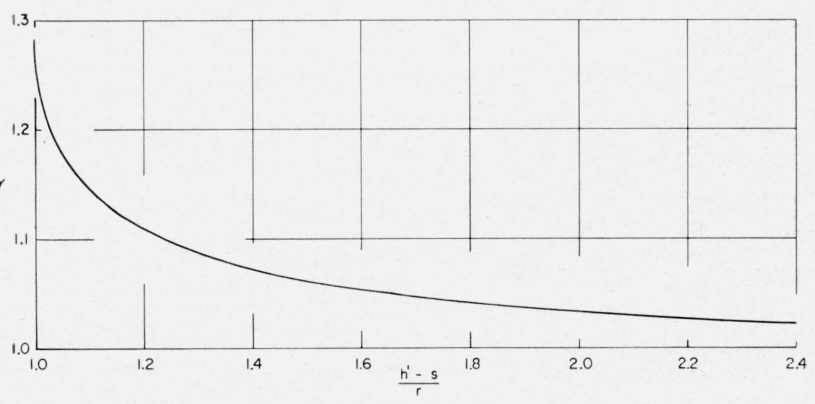

FIGURE 17. Variation of radius factor with distance below the surface.

increased wave heights when the cylinder touches the free surface found in section 4.

Letting $\phi^{\prime}$ be the velocity potential of the upper layer and $\phi$ that of the lower we write, after superposing a velocity $U$ on the system,

$\phi^{\prime}=-U x\left[1+\frac{(\gamma r)^{2}}{x^{2}+(s-y)^{2}}+\frac{(\gamma r)^{2}}{x^{2}+\left(2 h^{\prime}-s-y\right)^{2}}\right]+\chi^{\prime}+\chi_{1}^{\prime}$

and

$$
\phi=-U x\left[1+\frac{(\gamma r)^{2}}{x^{2}+(s-y)^{2}}+\frac{(\gamma r)^{2}}{x^{2}+\left(2 h^{\prime}-s-y\right)^{2}}\right]+\chi+\chi_{1}
$$

Thus the normal velocity at the cylinder is zero provided $\chi^{\prime}+\chi_{1}^{\prime}$ is negligible there. The origin is taken at the undisturbed level of the interface directly below the center of the cylinder. The $y-$ coordinate is positive upwards and $x$ is positive to the right in figure 5 .

If $r /(s+h)$ is small the normal component of velocity at the bottom from the terms in the bracket would vanish. Again $\chi+\chi_{1}$ and $\chi^{\prime}+\chi_{1}^{\prime}$ are so selected that the normal components of velocity due to these terms vanish at the surface and at the bottom. Thus assume

$$
\begin{aligned}
& \chi^{\prime}=\int_{0}^{\infty} \alpha^{\prime}(k) \cosh k\left(y-h^{\prime}\right) \sin k x d k \\
& \chi_{1}^{\prime}=\int_{0}^{\infty} \alpha_{1}^{\prime}(k) \cosh k\left(y-h^{\prime}\right) \cos k x d k
\end{aligned}
$$

and

$$
\begin{gathered}
\chi=\int_{0}^{\infty} \alpha(k) \cosh k(y+h) \sin k x d k \\
\chi_{1}=\int_{0}^{\infty} \alpha_{1}(k) \cosh k(g+h) \cos k x d k
\end{gathered}
$$

where $\alpha^{\prime}(k)$ and $\alpha(k)$ are to be determined. For the equation of the interface, assumed to be steady, we put

$$
\eta=\int_{0}^{\infty} \beta(k) \cos k x d x
$$


and

$$
\eta_{1}=\int_{0}^{\infty} \beta_{1}(k) \sin k x d k
$$

The kinematic boundary conditions at the interface require that

$$
U \frac{d}{d x}\left(\eta+\eta_{1}\right)=-\left[\frac{\partial \phi^{\prime}}{\partial y}\right]_{y=0}=-\left[\frac{\partial \phi}{\partial y}\right]_{y=0} .
$$

Equations (1) and (2) may be written in the form

$$
\begin{aligned}
& \phi^{\prime}=-U x-U(\gamma r)^{2} \int_{0}^{\infty}\left[e^{-k(s-y)}+e^{-k\left(2 h^{\prime}-s-y\right)}\right] \\
& \sin k x d k+\chi^{\prime}+\chi_{1}^{\prime}
\end{aligned}
$$

and

$$
\begin{array}{r}
\phi=-U x-U(\gamma r)^{2} \int_{0}^{\infty}\left[e^{-k(s-y)}+e^{-k\left(2 h^{\prime}-s-y\right)}\right] \\
\sin k x d k+\chi+\chi_{1}
\end{array}
$$

for $s-y>0$. Differentiating eq (5) with respect to $x$ and eq (3), (4), (7), and (8) with respect to $y$, eq (6) yields

$$
\alpha^{\prime}(k) \sinh k h^{\prime}=-\alpha(k) \sinh k h
$$

so that

$\alpha^{\prime}(k)=-\frac{U}{\sinh k h^{\prime}}\left\{\beta(k)+(\gamma r)^{2}\left[e^{-k s}+e^{-k\left(2 h^{\prime}-s\right)}\right]\right\}$

and

$$
\alpha(k)=\frac{U}{\sinh k h}\left\{\beta(k)+(\gamma r)^{2}\left[e^{-k s}+e^{-k\left(2 h^{\prime}-s\right)}\right]\right\} .
$$

Also

$$
\alpha_{1}^{\prime}(k) \sinh k h^{\prime}=\alpha_{1}(k) \sinh k h=\beta_{1}(k)
$$

So the terms $\chi_{1}^{\prime}, \chi_{1}$, and $\eta_{1}$ correspond to a system of free waves and will be dropped from the equations.

If the pressure at the free surface is taken as zero

$$
\frac{p^{\prime}}{\rho^{\prime}}=-g y-\frac{1}{2}\left(\frac{\partial \phi^{\prime}}{\partial x}\right)^{2}+g h^{\prime}+\frac{1}{2} U^{2}
$$

and

$$
\frac{p}{\rho}=-g y-\frac{1}{2}\left(\frac{\partial \phi}{\partial x}\right)^{2}+\frac{\rho^{\prime}}{\rho}\left(g h^{\prime}+\frac{U^{\varepsilon}}{2}\right)
$$

provided that $\rho^{\prime} / \rho$ is nearly unity. Letting $p^{\prime}=p$ for $y=\eta$ and omitting higher order terms in the disturbance

$$
\begin{array}{r}
\rho^{\prime} \int_{0}^{\infty}\left\{g \beta(k)+U^{2}(\gamma r)^{2} k\left[e^{-k s}+e^{-k\left(2 h^{\prime}-s\right)}\right]\right. \\
\left.-U k \alpha^{\prime}(k) \cosh k h^{\prime}\right\} \cos k x d k \\
=\rho \int_{0}^{\infty}\left\{g \beta(k)+U^{2}(\gamma r)^{2} k\left[e^{-k s}+e^{-k\left(2 h^{\prime}-s\right)}\right]\right. \\
-U k \alpha(k) \cosh k h\} \cos k x d k
\end{array}
$$

or

$$
\begin{array}{r}
\int_{0}^{\infty}\left\{U^{2}(\gamma r)^{2} k\left[e^{-k s}+e^{-k\left(2 h^{\prime}-s\right)}\right]\left(\rho^{\prime}-\rho\right)\right. \\
+g \beta(k)\left(\rho^{\prime}-\rho\right)-\rho^{\prime} U k \alpha^{\prime}(k) \cosh k h^{\prime} \\
+\rho U k \alpha(k) \cosh k h\} \cos k x d k=0
\end{array}
$$

Introducing $\alpha^{\prime}(k)$ and $\alpha(k)$ from eqs (10) and"(11)

$U^{2}(\gamma r)^{2} k\left[e^{-k s}+e^{-k\left(2 h^{\prime}-s\right)}\right]\left[\left(\rho^{\prime}-\rho\right)\right.$

$$
\begin{array}{r}
\left.+\rho^{\prime} \operatorname{coth} k h^{\prime}+\rho \operatorname{coth} k h\right]+\beta(k)\left[g\left(\rho^{\prime}-\rho\right)\right. \\
\left.+U^{2} k \rho^{\prime} \operatorname{coth} k h^{\prime}+U^{2} k \rho \operatorname{coth} k h\right]=0
\end{array}
$$

or

$$
\begin{aligned}
& \beta(k)=-(\gamma r)^{2} \\
& \left\{1-\frac{\left(\rho^{\prime}-\rho\right)\left(\frac{g}{U^{2}}-k\right)}{\rho^{\prime}\left[\frac{g}{U^{2}}+k \operatorname{coth} k h^{\prime}\right]-\rho\left[\frac{g}{U^{2}}-k \operatorname{coth} k h\right]}\right\} \\
& {\left[e^{-k s}+e^{-k\left(2 h^{\prime}-s\right)}\right] \text {. }}
\end{aligned}
$$

Now eq (5) becomes

$$
\begin{gathered}
\eta=-(\gamma r)^{2} \int_{0}^{\infty}\left(\rho^{\prime}-\rho\right)\left(\frac{g}{U^{2}}-k\right) \\
\left\{1-\frac{g}{\rho^{\prime}\left[\frac{g}{U^{2}}+k \operatorname{coth} k h^{\prime}\right]-\rho\left[\frac{g}{U^{2}}-k \operatorname{coth} k h\right]}\right. \\
\cdot\left[e^{-k s}+e^{-k\left(2 h^{\prime}-s\right)}\right] \cos k x d k
\end{gathered}
$$

or

$$
\begin{aligned}
\eta=-(\gamma r)^{2}\left[\frac{s}{x^{2}+s^{2}}+\frac{2 h^{\prime}-s}{x^{2}+\left(2 h^{\prime}-s\right)^{2}}\right] \\
+(\gamma r)^{2} \int_{0}^{\infty} \frac{\left(\rho^{\prime}-\rho\right)\left(\frac{g}{U^{2}}-k\right)\left[e^{-k s}+e^{-k\left(2 h^{\prime}-s\right)}\right]}{\rho^{\prime}\left[\frac{g}{U^{2}}+k \operatorname{coth} k h^{\prime}\right]-\rho\left[\frac{g}{U^{2}}-k \operatorname{coth} k h\right]} \\
\times \cos k x d k .
\end{aligned}
$$

The integral in eq (19) is improper, the denominator becoming zero at the value of $k$ for which

$$
k\left[\rho \operatorname{coth} k h+\rho^{\prime} \operatorname{coth} k h^{\prime}\right]=\frac{g}{U^{2}}\left(\rho-\rho^{\prime}\right) .
$$

This value, $k_{0}=2 \pi / \lambda$, corresponds to the wavelength of free interfacial waves at the velocity $U$, as derived in section 4. As $U$ increases the wavelength $\lambda$ also increases. Taking the limit of eq (20) as $k \rightarrow 0$ we have

$$
\frac{\rho}{h}+\frac{\rho^{\prime}}{h^{\prime}}=\frac{g}{U_{c}^{2}}\left(\rho-\rho^{\prime}\right)
$$


or

$$
U_{c}=\sqrt{\frac{g\left(\rho-\rho^{\prime}\right) h h^{\prime}}{\rho h^{\prime}+\rho^{\prime} h}}
$$

which is the velocity of propagation of long waves.

For larger values of $U$ there is no real singularity of the integrand in eq (19). Taking the principal value of the integral in eq (19) for $x$ positive,

$$
\begin{aligned}
\eta= & -(\gamma r)^{2}\left\{\left[\frac{s}{x^{2}+s^{2}}+\frac{2 h^{\prime}-s}{x^{2}+\left(2 h^{\prime}-s\right)^{2}}\right]+\frac{\pi\left(\rho^{\prime}-\rho\right)\left(\frac{g}{U^{2}}-k_{0}\right)\left[e^{-k_{0} s}+e^{-k_{0}\left(2 h^{\prime}-s\right)}\right] \sin k_{0} x}{\rho^{\prime}\left[\operatorname{coth} k_{0} h^{\prime}-k_{0} h^{\prime} \operatorname{csch}^{2} k_{0} h^{\prime}\right]+\rho\left[\operatorname{coth} k_{0} h-k_{0} h \operatorname{csch}^{2} k_{0} h\right]}\right. \\
& \left.-\int_{0}^{\infty} \frac{\left(\rho^{\prime}-\rho\right) \frac{g}{U^{2}}\left[\sin m s+\sin \left(2 m h^{\prime}-m s\right)\right] e^{-m x}}{\rho^{\prime}\left[\frac{g}{U^{2}}+m \cot m h^{\prime}\right]-\rho\left[\frac{g}{U^{2}}-m \cot m h\right]} d m-\int_{0}^{\infty} \frac{\left(\rho^{\prime}-\rho\right) m\left[\cos m s+\cos \left(2 m h^{\prime}-m s\right)\right] e^{-m x}}{\rho^{\prime}\left[\frac{g}{U^{2}}+m \cot m h^{\prime}\right]-\rho\left[\frac{g}{U^{2}}-m \cot m h\right]} d m\right\}
\end{aligned}
$$

For large values of $x$ only the second term is significant. Since $\eta$ is an even function of $x$, eq (5), the corresponding expression with $x$ replaced by $-x$ holds for negative $x$. Adding a system of free waves to cancel the disturbance far upstream, the result is

$$
\begin{aligned}
\eta= & -(\gamma r)^{2}\left\{\left[\frac{s}{x^{2}+s^{2}}+\frac{2 h^{\prime}-s}{x^{2}+\left(2 h^{\prime}-s\right)^{2}}\right]+\frac{2 \pi\left(\rho^{\prime}-\rho\right)\left(\frac{g}{U^{2}}-k_{0}\right)\left[e^{-k_{0} s}+e^{-k_{0}\left(2 h^{\prime}-s\right)}\right] \sin k_{0} x}{\rho^{\prime}\left[\operatorname{coth} k_{0} h^{\prime}-k_{0} h^{\prime} \operatorname{csch}^{2} k_{0} h^{\prime}\right]+\rho\left[\operatorname{coth} k_{0} h-k_{0} h \operatorname{csch}^{2} k_{0} h\right]}\right\} \\
& + \text { etc for } x>0
\end{aligned}
$$

and

$$
\eta=-(\gamma r)^{2}\left[\frac{s}{x^{2}+s^{2}}+\frac{2 h^{\prime}-s}{x^{2}+\left(2 h^{\prime}-s\right)^{2}}\right]+\text { etc for } x<0 .
$$

Thus there is a local disturbance followed by progressive waves of length $\lambda$, where

$$
\lambda=\frac{2 \pi}{k_{0}}
$$

is determined by eq (20).

\section{Comparison With Observation}

Recalling the conditions of the theory, it is clear that it does not apply to the translation waves of either section 5 or 6 . For a comparison with the observed progressive waves, when $h=h^{\prime}$, eq (20) gives

$$
4 \pi \frac{h}{\lambda} \operatorname{coth} \frac{2 \pi h}{\lambda}=\frac{\Delta \rho}{\rho} \frac{g h}{U^{2}}
$$

which can be solved numerically to give $\lambda / h$ as a function of $U^{2} /(\Delta \rho / \rho) g h$.

The values are given by the curves in figures 6,7 , and 8 . The agreement with experiment is good for

$$
\frac{U^{2}}{\frac{\Delta \rho}{\rho} g h}<0.3
$$

Regarding the wave height $a$, we have from eq (23)

$$
\frac{a}{r}=\gamma^{2} \frac{r}{h} \frac{\pi \frac{\Delta \rho}{\rho}\left(\frac{g h}{V^{2}}-k_{c} h\right)\left[e^{\left.-k_{0} h \frac{s}{h}+e^{-k_{0} h}\left(2-\frac{s}{h}\right)\right]}\right.}{\operatorname{coth} k_{0} h-k_{0} h \operatorname{csch}^{2} k_{0} h}
$$

approximately. Thus $a / r$ is a function of $U^{2} /(\Delta \rho / \rho g h$ for given values of $s / h$ and $r / h$. In figure 18 one of the theoretical curves is given along with the corresponding experimental points. For small wave heights the observed values are considerably greater than the theoretical values. This disparity may be due to the wake produced by the cylinder or the limitation of the theory to small waves. For the smallest waves which could be measured accurately, figure 18 , the observed values are approximately twice as large as predicted by theory. It appears that the disparity between observed and theoretical wave heights is largely due to the wake produced by the cylinder. 


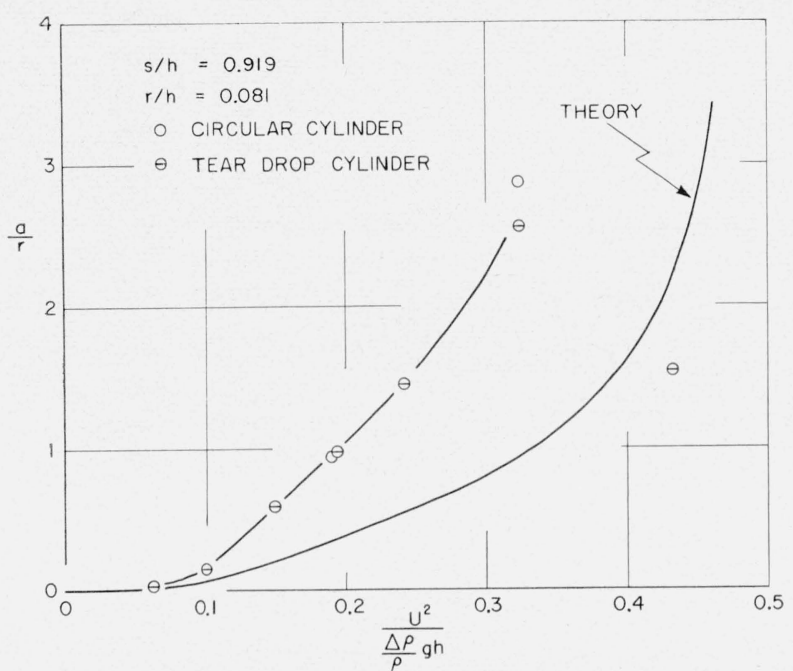

Figure 18. Variation of wave height of internal oscillatory waves; comparison with theory.

\section{Summary}

The disturbances created at the interface of a two-layer liquid system by the horizontal motion of a cylinder in the upper layer fall into three categories. First, when the layers are of equal thickness, in most cases a train of progressive oscillatory waves is produced at the interface. Second, when the depth of the lower layer is much less than the depth of the fresh-water layer, the profile of the interface usually resembles that corresponding to a succession of positive internal solitary waves. Third, when the depth of the lower layer is much greater than the depth of the fresh-water layer, in most cases an internal hydraulic jump is produced. The exceptional cases correspond to low cylinder velocities. The theory for disturbances of small amplitude predicts waves of the type observed in the first category, but the observed amplitudes are greater by a factor of two in those cases where the conditions of the theory are most nearly satisfied. This discrepancy is ascribed to the effect of the wake behind the cylinder.

For the progressive oscillatory waves there is a distinct change in the manner of variation of the wave heights corresponding to $\left.U^{2} / \Delta \rho / \rho\right) g h=0.3$ where the wave height reaches a maximum. For $U^{2} /(\Delta \rho / \rho) g h<0.3$ the wave height $a / r$ depends primarily on the quantity $U^{2} /(\Delta \rho / \rho) g s$ while for $U^{2} /(\Delta \rho / \rho) g h>0.3$ the wave height depends on
$U^{2} /(\Delta \rho / \rho) g h$. Figure 12 shows that the wave height increases as $r / s$ is increased.

The experiments with different shapes of cylinders did not yield a significant difference in the disturbances produced. This may be due to the manner in which the wake depends on the cylinder shape.

\section{References}

11] G. G. Stokes. On the theory of oscillatory waves, Trans. Camb. Phil. Soc. 8, 441 (1847) (Papers I).

[2] R. R. Webb. Math. Tripos Papers (1884).

[3] A. G. Greenhill. Wave motion in hydrodynamics, J. Math. IX, 62, (1887).

[4] W. Burnside. On the small wave motion of a hetrogeneous fluid under gravity, Proc. London Math. Soc. (1), 392 (1889).

[5] A. E. H. Love. Wave motion in a hetrogeneous heavy liquid, Proc. London Math. Soc. 22, 307 (1891).

[6] Lord Rayleigh, Investigation of the character of the equilibrium of an incompressible heavy liquid of variable density, Proc. London Math. Soc. (1) 14, 170 (1891) (Papers II, 200).

[7] Sir Horace Lamb. On atmospheric oscillations, Proc. Roy Soc. 84, 566, 571 (1910).

[8] V. W. Ekman. On dead water, Scientific results of the Norwegian North Polar expedition, pt XV, Christiania, 1904.

[9] N. Zeilon. On tidal boundary waves and related hydrodynamical problems, Kungl. Svenska Vetenskapsaksademiens Handlingar Band 47, No. 4 (1912).

[10] R. R. Long. Some aspects of flow of stratified fluids I. A theoretical investigation, Tellus 5, 42-58 (1953).

[11] R. R. Long. Some aspects of flow of stratified fluids III. Continuous density gradients, Tellus $\boldsymbol{\gamma}, 341$ (1955).

[12] R. R. Long. Some aspects of flow of stratified fluids II. Experiments with a two fluid system, Tellus 6, 97 (1954).

[13] M. Tepper. A proposed mechanism of squall lines - the pressure jump line, J. Meteor. 7,21 (1950).

[14] C. G. Rossby. On the vertical and horizontal concentration of momentum in air and ocean currents, Tellus $\mathbf{3}$, 15 (1951).

[15] A. Craya. Critical regimes of flows with density stratification, Tellus 3, 28 (1951).

[16] G. S. Benton. The occurrence of critical flow and hydraulic jumps in a multi-layer system, Tech. Rept. No. 1 (The Johns Hopkins University, Dept. of Civ. Eng., 1953).

[17] C. S. Yih and C. R. Guha. Hydraulic jump in a fluid system of two layers, Tellus $\boldsymbol{\gamma}, 358$ (1955).

[18] G. H. Keulegan. Characteristics of internal solitary waves, J. Research NBS 51 (1953) RP2442.

[19] R. R. Long. The solitary wave in one and two fluid systems, Tellus 8, 460 (1956).

[20] G. H. Keulegan. An experimental study of internal solitary waves, NBS Report to Chief of Engineers, U.S. Army, Tenth progress report on model laws for density currents (Nov. 28, 1955).

[21] H. Lamb. Hydrodynamies, Sixth Ed. (Cambridge Univ. Press).

[22] L. H. Carpenter. On the motion of two cylinders in an ideal fluid, J. Research NBS 61, 2 (1958) RP2889.

(Paper 64C3-42) 


\section{Publications of the National Bureau of Standards*}

\section{Selected Abstracts}

Phase shift effects in Fabry-Perot interferometry, C. J. Koester, J. Research NBS 64A, No. 3, May-June 1960.

A method is demonstrated for utilizing in Fabry-Perot interferometry the data on reflection phase shift dispersion obtained from fringes of equal chromatic order. Unknown wavelengths can be calculated from the Fabry-Perot patterns obtained with a large etalon spacing, even without prior knowledge of the phase shift of the reflecting surfaces. When the theoretical phase shift as a function of wavelength is known approximately, then the correct orders of interference can be determined for both the Fabry-Perot fringes and fringes of equal chromatic order. From the wavelengths of the latter the phase shift dispersion can be measured to an accuracy of about $10 \mathrm{~A}$. The method is especially useful for reflectors with large dispersion of phase shift, such as multilayers. Results in the visible spectrum are reported for aluminum films and a pair of dielectric 15 layer broad-band reflectors.

Separation and determination of small quantities of aluminum in steel, B. B. Bendigo and R. K. Bell, J. Research NBS 64A, No. S, May-June 1960.

A method is described for determining small amounts of aluminum (0.01 to 0.3 percent) in carbon and stainless steels. A perchloric-sulfuric acid solution of the steel is electrolyzed in a mercury cathode cell to remove most of the iron, and a chloroform extraction removes elements such as aluminum, residual iron, and titanium as cupferrates from a solution buffered at $p \mathrm{H}$ 3.5. These elements are converted from cupferrates to perchlorates; all except aluminum are then extracted as cupferrates with chloroform from $4 N$ hydrochloric acid. Aluminum in the acid solution is determined photometrically, using aluminon (ammonium aurintricarboxylate) and a wavelength of approximately $540 \mathrm{~m} \mu$. Accuracy to within \pm 0.005 percent aluminum is indicated.

A symmetric continuous poker model, A. J. Goldman and J. J. Stone, J. Research NBS 64B, No. 1, January-March 1960. Beginning with Von Neumann, mathematicians concerned with the rational analysis of conflict situations have realized that investigation of accurate or simplified versions of common card games leads to techniques and insights applicable to situations of military or economic interest. In the present paper, a symmetric poker model one stage more complicated than the original Von Neumann game is solved. There are two bet levels $a, b$ and an ante of 1 unit $(a>b>1)$; no raises are permitted. The game has a unique optimal strategy, which forbids bluffing on a low hand. The limiting case $b=1$ is shown to yield the Von Neumann model.

Characteristics of 488 megacycles per second radio signal reflected from the moon, B. C. Blevis and J. H. Chapman, $J$. Research NBS 64D, No. 4, July-August 1960.

Radio signals at $488 \mathrm{Mc}$, received after reflection from the moon, have been studied using a continuous wave bistatic radar system located near Ottawa, Canada. These experiments were carried out during 1957 and consisted of monitoring the signals received on two orthogonal dipoles mounted at the focus of a 28-foot parabolic tracking antenna. The total mean received signal yielded an effective radar cross section of the moon at this frequency of 0.05 of the projected area. The libration fading as observed in the two orthogonal receiver channels was in sychronism, with a cross-correlation coefficient of 0.89 . It was established that the signal is not depolarized significantly on reflection at the surface of the moon, or in passing through the ionosphere. Rotation of the plane of polarization of the radio wave in the double passage through the ionosphere was observed to change by nearly
180 degrees over a 6-hour period during quiet ionospheric conditions.

The use of polarization fading of satellite signals to study the electron content and irregularities in the ionosphere, C. G. Little and R. S. Lawrence, J. Research NBS 64D, No. 4, July-A ugust 1960 .

A procedure is described for using the Faraday-rotation fading of a satellite radio signal to measure the ionospheric electron content per unit column up to the height of the satellite. Full account is taken of ionospheric refraction by using the collision-free form of the Appleton-Hartree equation. Results based on observations of 1958 Delta 2 are presented. The sub-satellite electron contents derived throughout the satellite passes for heights below the $F$-peak compare well with values deduced from simultaneous ionograms. Ionospheric irregularities, having lateral dimensions of a few hundred kilometers, and fractional deviations in sub-satellite electron content of about 0.02 have been detected. Our observations suggest that satellite polarization studies offer important advantages over other methods of investigating these irregularities.

Determination of piezoelectric properties as a function of pressure and temperature, J. E. McKinney and C. S. Bowyer, J. Acoust. Soc. Am. 32, No. 1, 56 (1960).

Piezoelectric data on a mixed titanate system $\left(82 \% \mathrm{BaTiO}_{3}\right.$, $9.1 \% \mathrm{CaTiO}_{3}, 3.6 \% \mathrm{PbTiO}_{3}$, and $4.4 \% \mathrm{TiO}_{2}$ ) was obtained from an apparatus intended to measure the dynamic compressibility of materials. The calibration constant of the apparatus involves the piezoelectric and dielectric constants of the ceramics used as transducers. The method is discussed and an operating equation for the apparatus derived. Piezoelectric and dielectric constants have been measured over a fairly extensive temperature and pressure range and an apparent phase transition observed near $5^{\circ} \mathrm{C}$. This transition corresponds to that found in pure barium titanate, and might be due to imperfect mixing of the titanates that leaves a small amount of pure barium titanate present. The method described appears more sensitive for the detection of changes in crystal symmetry in such materials than either X-ray or dielectric measurements.

Determination of the recording performance of a tape from its magnetic properties, E. D. Daniel and I. Levine, J. Acoust. Soc. Am. 32, No. 2, 258 (1960).

This is the second of two papers. The first (I) dealt with the general magnetic properties of recording tape. The present paper gives an analysis of hf biased recording based upon the anhysteretic properties of the tape as specified in I. Calculations of performance are compared with the results of absolute measurements carried out on a conventional recording machine, and on large scale models. Satisfactory agreement is obtained when the theory is corrected to take into account a loss attributed largely to a dynamic form of demagnetization which takes place during recording. The corrected theory can be used to compare tape performance under a variety of operating conditions without reference to a particular test recorder. Attention is confined to recorded wavelengths which are large compared with coating thickness.

Gages for measuring the thickness of chromium on the internal surface of small-bore tubes, V. A. Lamb and P. A. Krasley, Plating 47, No. 2, 176 (1960).

Two gages of the eddy-current type for measuring the thickness of chromium coatings on the internal surface of caliber .30 and caliber .50 gun barrels have been developed. Measurements are nondestructive and are localized to a small area, less than $1 / 8$ inch diameter. The gages may readily be modified to be generally applicable to the measurement of the thickness of various coatings on the internal surfaces of metallic tubes of the same or larger diameters. 
Experimental and theoretical investigation of the magnetic properties of iron oxide recording tape, E. D. Daniel and I. Levine, J. Acoust. Soc. Am. 32, No. 1, 1 (1960).

Part A gives the results of remanent magnetization tests made under ordinary and anhysteretic conditions, and shows that the major anhysteretic properties of a recording tape can be expressed in terms of three easily measured constants. The design of the test equipment is discussed and test results are listed for thirteen representative types of tape. Part B reviews some of the theories of fine particle magnets that can be applied to recording tape, and gives an extensive treatment of remanent magnetization based upon the Preisach diagram. Some aspects of the Preisach diagram treatment may be of interest to workers outside the magnetic recording field. The anhysteretic properties are important in $\mathrm{hf}$ biased recording and a second paper describes how these properties can be used to predict certain recording performance characteristics.

Efficient harmonic generation, G. F. Montgomery, Proc. IRE 48, No. 2, 251 (1960).

An harmonic generator using a rectifier multiplier followed by an amplifier is more efficient than its equivalent class-C multiplier. A proposed rectifier-transistor harmonic generator is capable of high efficiency that is nearly independent of harmonic number.

Precise measurement of heat of combustion with a bomb calorimeter, R. S. Jessup, NBS Monograph 7 (1960).

This Monograph gives detailed descriptions of apparatus and methods which are used at the National Bureau of Standards for precise determinations of heats of combustion of liquid hydrocarbon fuels. Numerical examples are given of methods of calculating results of measurements from observed data. The technique of making and filling glass bulbs to contain samples of volatile liquid fuels is described.

The accuracy of the methods described is about 0.1 percent. This is intermediate between the accuracy of 0.01 or 0.02 percent attained in certain measurements on pure compounds, and the accuracy of several tenths of one percent obtainable with published standard procedures for measurements on fuels.

Conductive flooring for hospital operating rooms, T. H. Boone, F. L. Hermach, E. H. MacArthur, and R. C. McAuliff, NBS Monograph 11 (1960).

Characteristics and performance of available types of conductive flooring materials were investigated in the laboratory. The study showed that the electrodes and instruments used to measure the floor greatly affected the measured resistance, but that the method specified by the National Fire Protection Association for measuring the electrical resistance reasonably simulated the conditions under which a floor functions in reducing electrostatic hazards. The physical, chemical, and serviceability characteristics of conductive floorings investigated showed results comparable with those of nonconductive flooring of the same type. Consequently, with some limitations, an architect may base his choice of a conductive flooring material on his knowledge of the behavior of similar nonconductive materials.

Tabulation of data on receiving tubes, C. P. Marsden, W. J. Keery, and J. K. Moffitt, NBS Handb. 68 (1959).

A tabulation of Receiving Type Electron Tubes with some characteristics of each type has been prepared in the form of two major listings, a Numerical Listing in which the tubes are arranged by type number, and a Characteristic Listing in which the tubes are arranged by tube type and further ordered on the basis of one or two important parameters. The tabulation is accompanied by a listing of similar tube types and basing diagrams for the listed tubes.

Are life testing procedures robust? M. Zelen and M. C. Dannemiller, Proc. 6th Natl. Symp. Reliability and Quality Control in Electronics, Jan. 11-13, 1960, Inst. Radio Engrs. Inc., p. 185 (1960).

Almost all the statistical procedures in current use for evaluating the reliability of components or equipments rest on the assumption that the failure times follow the exponential distribution. In practical situations one rarely has enough data to determine whether failure times are actually exponential. This paper studies the behavior of several statistical life testing procedures based on the exponential failure law if the true failure law is the Weibull distribution. It is found that these statistical techniques, which are widely used, are very sensitive to departures from initial assumptions. Applying these techniques to life test data when the exponential failure law is not satisfied may result in substantially increasing the probability of accepting components or equipments having poor reliability.

Improved NBS abrasive jet method for measuring abrasion resistance of coatings, A. G. Roberts, ASTM Bull. No. 244 , 48 (TP52) (1960).

A description is given of the changes made in the NBS Abrasive Jet Method since publication of the original article describing this rapid, reproducible, and versatile means for measuring the abrasion resistance of organic and other coatings. Improvements include use of a free-flowing abrasive, a redesigned abrasive sifting chamber to minimize turbulence and interference effects, better control of abrasive flow, addition of an electronic contact device for setting nozzle-to-coating distance, and automatic timing. Precision of measurement has been significantly increased by use of a reference panel.

Flame-spread measurements by the radiant panel flamespread method, D. Gross, Forest Products J. X, No. 1, 33 (1960)

The results of a limited number of tests for evaluation of the flame spread properties of untreated and of fire-retardant coated wood-base materials are presented. It is shown by use of the radiant panel flame spread test method that variations in moisture content and mean density can have a significant effect upon the flame spread index of untreated wood. For the same mean density and moisture content, it was observed that variations in the surface grain structure of untreated wood had an appreciable effect upon the flame spread index. The flame spread indices of the fire-retardant coated assemblies were considerably lower than those obtained with uncoated or conventionally coated materials although significant differences between coated assemblies were observed. A test method such as this can be used to advantage for the development and evaluation of effective and practical fire-retardant coatings for wood-base materials.

Report of the 44th National Conference on Weights and Measures 1959, NBS Misc. Publ. 228 (1959).

This is a report of the proceedings (edited) of the Fortyfourth National Conference on Weights and Measures, sponsored by NBS, held in Washington, D.C., June 8-12, 1959, and attended by State, county, and city weights and measures officials, and representatives of the Federal Government, business, industry, railroads, and associations.

What price accurate test methods? A. T. MePherson, ASTM Bull. (ACR Notes Column) No. 244, 7 (1960).

Inaccurate test methods used in specifications frequently lead to difficulty, misunderstandings, and unnecessary rejections because much of the tolerance that is allowed in dimensions, composition, or other characteristics of a product may be taken up by the uncertainty in testing. Accurate methods can pay dividends by lowering the rejection rate, avoiding referee tests and other sources of delay, and affording greater assurance that products which are found by test to comply with the specification will actually serve the intended purpose. A further saving may be effected with many products by widening the tolerances and thereby reducing the cost of production. The development of accurate test methods, however, may require long and expensive research. Before undertaking to develop any specific new test method, a critical survey should be made to determine whether the anticipated savings and other benefits will exceed the probable cost. Such a survey will involve both economic and technical factors and may well make use of methods and techniques which are employed in market research. 
Many changes reflected in new dry cell standard, W. J. Hamer, Mag. of Standards 31, No. 3, 81 (1960).

The seventh edition of the American Standard Specification for Dry Cells and Batteries was published in December 1959 as Handbook 71 of the National Bureau of Standards. It supersedes the previous specification which was published in 1954 as Circular 559 of the National Bureau of Standards. The new specification includes many changes. Cell dimensions are given in both the English and metric systems: the metric system was added in line with the trend toward its increased use in commerce and industry. Cell and battery designations recommended by $\mathrm{TC}-35$ Committee on Primary Cells and Batteries of the International Electrotechnical Commission was incorporated in keeping with attempts to secure international cooperation in the standardization of primary batteries. The most notable change in the new specification is the inclusion, for the first time, of cells and batteries for use with transistorized circuits. Other minor changes include a new test for lantern batteries used in alarm circuits, some new terminal designs, and the dropping of specifications for batteries to be used with "carbontype" hearing aids since these types of instruments are rapidly becoming obsolete.

Water penetration testing machine for sole leather, T. J Carter, J. Am. Leather Chem. Assoc. LV, No. 3, 139 (1960). A test to measure the water resistance of sole leather has been developed. A leather specimen is flexed at a frequency of 30 cycles per minute with one side exposed to water until penetration occurs. The specimen is clamped so that the angle of bend is approximately $90^{\circ}$. The results show that flexing increases the rate of water absorption as well as the rate of water penetration compared to the rates under static conditions. Studies were made on the influence of thickness of specimen, location on the sole leather bend, and compression of the specimen on dynamic water penetration and water absorption. The logarithm of the number of flexes required for penetration is a direct function of the thickness of the leather. The rates of water penetration and water absorption depend on the location of the specimen on the sole leather bend. Compression of the impregnated leather decreases the rate of water penetration and the rate of water absorption.

Bending and stretching of corrugated diaphragms, R. F. Dressler, Trans. ASME 81D, No. 4, 651 (1959).

Solutions of the exact linear elastic shell equations for all stresses and displacements in a typical corrugated diaphragm are presented for three cases over a 9 to 1 range of thicknesses. Results were obtained by numerical integration in an electronic digital computer. The effect of thickness variation is discussed with respect to both stresses and resultants, and peak values needed for design purposes are presented. Circumferential and meridional stresses are found to be equally important throughout the thickness range analyzed. Bending and membrane stresses are likewise equally important throughout the range. Peak values in some cases occur near the outer rim.

Triaxial tension at the head of a rapidly running crack in a plate, J. M. Frankland, Trans. ASME, Ser. E $\mathbf{2 6}$, No. 4, 570 (1959).

Two-dimensional solutions have been found for the state of stress in a plate loaded in tension at right angles to a crack. One of these concerns the stationary crack and the other an advancing crack. No three-dimensional solutions are available. It is shown, however, that it is highly probable that cracks propagating at high speeds develop an appreciable triaxial tension near the head of the crack. This is believed to be significant with regard to the observed brittle behavior of plates under such circumstances.

Transistor P-A amplifier, G. F. Montgomery and F. R. Bretemps, Electronic Ind. 19, No. 1, 196 (1960).

A portable public-address amplifier using transistors and powered by flashlight cells develops an electrical power of about 0.75 watt and is useful for moderately large audiences. The complete unit consists of the amplifier, two loudspeakers, batteries, and a dynamic microphone and is contained in an attache case. Battery life is about 20 hours.

\section{Other NBS Publications}

Journal of Research, Section A. Physics and Chemistry, Volume 64A, No. 3, May-June 1960. 70 cents.

Phase shift effects in Fabry-Perot interferometry. C. J. Koester. (See above abstracts.)

Infrared absorption spectrum of methane from 2470 to 3200 $\mathrm{cm}^{-1}$. E. K. Plyler, E. D. Tidwell, and L. R. Blaine.

Elastic constants of synthetic single crystal corundum at room temperature. J. B. Wachtman, Jr., W. E. Tefft, D. G. Lam, Jr., and R. P. Stinchfield.

Radial distribution study of vitreous barium borate. A. Bienenstock, A. S. Posner, and S. Block.

Separation and determination of small quantities of aluminum in steel. B. B. Bendigo and R. K. Bell. (See above abstracts.)

Conformations of the pyranoid sugars. II. Infrared absorption spectra of some aldopyranosides. R. S. Tipson and H. S. Isbell.

Journal of Research, Section B. Mathematics and Mathematical Physics, Volume 64B, No. 2, April-June 1960. 75 cents.

Non-self-adjoint boundary value problems in ordinary differential equations. W. Greub and W. C. Rheinboldt.

Criteria for the existence and equioscillation of best Tchebvcheff approximations. J. R. Rice.

Note on the solution of Riccati's differential equation. H. H. Howe.

On a generalization of the index notation for absolute tensors of arbitrary order. E. H. Brown.

Upper and lower bounds for the center of flexure. L. E Payne.

Half-round inductive obstacles in rectangular wave guide. D. M. Kerns.

Journal of Research, Section D. Radio Propagation, Volume 64D, No. 4, July-August 1960. 70 cents.

Relation of turbulence theory to ionospheric scatter propagation experiments. A. D. Wheelon.

Propagation at oblique incidence over cylindrical obstacles. M. P. Bachynski.

Diffraction by smooth conical obstacles. H. E. J. Neugebauer and M. P. Bachysnki.

Characteristics of 488 megacycles per second radio signal reflected from the moon. B. C. Blevis and J. H. Chapman. (See above abstracts.)

The use of polarization fading of satellite signals to study the electron content and irregularities in the ionosphere. C. G. Little and R. S. Lawrence. (See above abstracts.)

Note on a test of the equivalence theorem for sporadic $E$ propagation. J. W. Wright and T. N. Gautier.

Daytime attenuation rates in the very low frequency band using atmospherics. W. L. Taylor.

Measured electrical properties of snow and glacial ice. A. D. Watt and E. L. Maxwell.

Some extremely low frequency phenomena. E. T. Pierce.

Mode theory and the propagation of extremely low frequency radio waves. J. R. Wait.

Studies of natural electric and magnetic fields. G. D. Garland and T. F. Webster.

Natural electromagnetic energy below the ELF range. W. H. Campbell.

Possible application of the system loss concept at extremely low frequencies. K. A. Norton.

Measurements of the spectrum of radio noise from 50 to 100 cycles per second. M. Balser and C. A. Wagner.

Half-wave cylindrical antenna in a dissipative medium: current and impedance. R. King and C. W. Harrison.

Standard X-ray diffraction powder patterns, H. E. Swanson, M. I. Cook, T. Isaacs, and E. H. Evans, NBS Circ. 539, Vol. 9, (1960) 40 cents.

Properties of high-temperature ceramics and cermetsElasticity and density at room temperature, S. M. Lang, NBS Monograph 6 (1960) 20 cents. 
Specification for dry cells and batteries, (supersedes NBS Cire. 559). NBS Handb. 71 (1959) 25 cents.

Research Highlights of the National Bureau of Standards Annual Report, Fiscal Year 1959. NBS Misc. Publ. 229 (1959) 55 cents.

Basic theorems in matrix theory, M. Marcus. NBS Applied Math. Series 57 (1960) 15 cents.

Survey of Central Radio Propagation Laboratory research in tropospheric propagation 1948-1956, J. W. Herbstreit and P. L. Rice, NBS Tech. Note 26 (PB151385) (1959) $\$ 4.00$.

An atlas of oblique-incidence ionograms, V. Agy, K. Davies, and R. Salaman, NBS Tech. Note 31 (PB151390) (1959) $\$ 2.25$.

Distribution of incoming lettermail at the Baltumore, Maryland City Post Office, B. M. Levin and A. E. Newman, NBS Tech. Note 33 (PB151392) (1959) \$2.50.

A multiplet table of astrophysical interest, C. E. Moore, NBS Tech. Note 36 (PB151395) (1959) \$4.00.

Application of RF micropotentiometers for calibration of signal generators to $1000 \mathrm{Mc}, \mathrm{L}$. F. Behrent, NBS Tech. Note 37 (PB151396) (1960) 50 cents.

Design and construction of a liquid hydrogen temperature refrigeration system, D. B. Chelton, J. W. Dean, and B. W. Birmingham, NBS Tech. Note 38 (PB151397) (1960) 75 cents.

Helium refrigeration and liquefaction using a liquid hydrogen refrigerator for precooling, D. B. Chelton, J. W. Dean, and T. R. Strobridge, NBS Tech. Note 39 (PB151398) (1960) 50 cents.

Mean electron density variations of the auiet ionosphere I-March 1959, J. W. Wright and L. A. Fine, NBS Tech. Note 40-1 (PB151399-1) (1960) \$1.25.

Mean electron density variations of the ouiet ionosphere 2-Aprll 1959, J. W. Wright and L. A. Fine, NBS Tech. Note 40-2 (PB151399-2) (1960) \$1.25.

Expendable modules as bases for disposal-at-failure maintenance, R. O. Stone, P. Meissner, and K. M. Schwarz, NBS Tech. Note 41 (PB151400) (1960) \$2.25.

Analog-digital conversion equipment for electrocardiographic data, L. Taback, NBS Tech. Note 42 (PB151401) (1960) $\$ 1.25$.

A summary of VHF and UHF tropospheric transmission loss data and their long-term variability, D. A. Williamson, V. L. Fuller, A. G. Longley, and P. L. Rice, NBS Tech. Note 43 (PB151402) (1960) \$2.25.

Tables for the statistical prediction of radio ray bending and elevation angle error using surface values of the ref ractive index, B. R. Bean, B. A. Cahoon, and G. D. Thayer, NBS Tech. Note 44 (PB151403) (1960) 50 cents.

Operating instructions for $\mathrm{ARN}-2$ auxiliary log-linear noise recorder, R. T. Disney and C. A. Samson, NBS Tech. Note 45 (PB151404) (1960) 50 cents.

Direction findings on whistlers, J. M. Watts, J. Geophys. Research 64, No. 11, 2029 (1959).

The construction of Hadamard matrices, E. C. Dade and K. Goldberg, Michigan Math. J. 6, 247 (1959).

Geomagnetic and ionospheric phenomena associated with nuclear explosions, S. Matsushita, Nature 184, BA33 (1959).

Stress corrosion cracking in low carbon steel, H. L. Logan, Proc. Phys. Met. Stress Corrosion Fracture Conf., Pittsburgh, Pa., Apr. 2-3, 1959, reprinted from Met. Soc. Conf., p. 295 (Interscience Publishers, New York, N.Y., 1959).

Higher oxides of silver, H. E. Swanson, J. Electrochem. Soc. 106, No. 12, 1073 (1959).

Oscillatory behavior of magnetic susceptibility and electronic conductivity, A. H. Kahn and H. P. R. Frederikse, ch. in Vol. IX, Adv. Solid State Phys., p. 257 (Academic Press Inc., New York, N.Y., 1959).

Geomagnetic activity following large solar flares, C. S. Warwick and R. T. Hansen, J. Atmospheric and Terrest. Phys. 14, 287 (1959)

Simplification of systems of units currently evolving in the electrical field, F. B. Silsbee, Systems of Units, Am. Assoc. Advance. Sci., p. 7 (1959).

Atoms and free radicals by $\gamma$-irradiation at $4.2^{\circ} \mathrm{K}, \mathrm{L} . \mathrm{A}$. Wall, D. W. Brown, and R. E. Florin, J. Phys. Chem. 63, $1762(1959)$
Rotation transfer in the fluorescence spectrum of $\mathrm{OH}\left({ }^{2} \Sigma^{+}\right)$ T. Carrington, J. Chem. Phys. 31, No. 5, 1418 (1959).

Poly (tetrafluorethylene) - a radiation-resistant polvmer, L. A. Wall and R. E. Florin, Letter to Ed., J. Appl. Polvmer Sci. III, No. 5, 251 (1959)

On the approximate daytime constancy of the absorption of radio waves in the lower ionosphere, S. Chapman and K. Davies, J. Atmospheric and Terrest. Phys. 13, No. 1-2, 86 (1958).

An X-ray crystallographic study of Schroeckingerite and its dehydration product, D. K. Smith, Am. Mineralogist 44, 1020 (1959)

Modular forms whose coefficients possess multiplicative properties, M. Newman, Ann. Math. $\mathbf{0 0} 478$ (1959).

A note on the scattering of electrons from atomic hydrogen, A. Temkin, Phys, Rev, 116, No. 2, 358 (1959)

The analysis of latin squares with a certain type of rowcolumn interaction, J. Mandel, Technometrics 1, No. 4, 379 (1959).

Design of free-air ionization chambers for the soft X-ray region $(20-100 \mathrm{kv})$, V. H. Ritz, Radiology $\mathbf{7 3}$, No. 6, 911 (1959).

Thermal conductivity of indium antimonide at low temperatures, E. V. Mielczarek and H. P. R. Frederikse, Phys. Rev. 115, 888 (1959).

Model for vibrational relaxation of diatomic gases behind shock waves, R. Herman and R. J. Rubin, Phys. of Fluids 2, No. 5, 547 (1959).

A note on algebras, A. J. Goldman, Am. Math. Mo, 66, 795 (1959).

Lnear differential equations of the second order with a large parameter, F. W. J. Olver, J. Soc. Indust. Appl. Math. 7, 306 (1959).

Sorting devices in postal tests. 1: Proposal for an electromagnetic sorter, S. Henig, Automatic Control 11, No. 6 6 (1959).

The dissociation constant of $\mathrm{CaOH}^{+}$from $0^{\circ}$ to $40^{\circ} \mathrm{C}, \mathrm{R} . \mathrm{G}$. Bates, V. E. Bower, R. G. Canham, and J. E. Prue, Trans. Faraday Soc. 55, No. 444, 2062 (1959).

Evaluation of chemical analyses on two rocks, W. J. Youden, Technometrics 1, No. 4, 409 (1959).

Nuclear electronics, L. Costrell, Nucleonics Mag. 18, No. 1, 124 (1960).

Microscopical studies of failure in polymers, S. B. Newman, ASTM Spec. Tech. Pub. 25\%, 132 (1959).

Flare-associated bursts at $18 \mathrm{Mc} / \mathrm{s}$, C. Warwick and J. W. Warwick, Paris Symp. on Radio Astron. (IAU Symp. No. 9 and URSI Symp. No. 1), p. 203 (1959).

Quantum-mechanical calculation of the probability of an exchange reaction for constrained linear encounters, J. Mazur and R. J. Rubin, J. Chem. Phys. 31, No. 5, 1395 (1959).

Monte Carlo calculations of gamma ray backscattering, M. J. Berger and D. J. Raso, Radiation Research 12, No. 1, 20 (1960).

On the diffraction of electromagnetic pulses by curved conducting surfaces, J. R. Wait and A. M. Conda, Can. J. Phys. 37, 1384 (1959).

Identification of textile coatings by infrared spectroscopy, F. H. Forziati, R. T. Hite, and M. K. Wharton, Am. Dyestuff Reptr. 49, No. 4, 29 (1960).

New wavelengths for some helium (He I) lines, W. C. Martin, J. Opt. Soc. Am. 50, No. 2, 174 (1960).

Geomagnetic effects of high-altitude nuclear explosions, A. G. McNish, J. Geophys. Research 64, No. 12, 2253 (1959).

Propagation and production of electromagnetic waves in a plasma, R. Gallet, Nuovo Cimento Suppl. 13, No. 1, 234 (1959).

Fading rate recorder for propagation research, J. W. Koch, W. B. Harding, and R. J. Jansen, Electronics 32, No. 51, $78(1959)$

Matrix algebra for calculating multicomponent mixtures, F. Ordway, Portland Cement Assoc. J. Research and Devel. Labs. 2, No. 1, 28 (1960).

Line shape and $f$ value in the $\mathrm{OH}^{2} \Sigma^{+}-2 \pi$ transition, T. Carrington, J. Chem. Phys. 31, No. 5, 1243 (1959). 
Leonard Euler's integral: A historical profile of the gamma function, P. J. Davis, Am. Math. Mo. 66, 849 (1959).

Departures from the Saha equation under varying conditions of Lyman continuous opacity, S. R. Pottasch and R. N. Thomas, Astrophys. 3. 130, No. 3, 941 (1959).

Vibration-rotation bands of ammonia. IV. The stretching fundamentals and associated bands near $3 \mu$, W. S. Benedict, F. K. Plyler, and E. D. Tidwell, J. Chem. Phys. 32, No. 1, $32(1960)$.

Electron impact studies of aromatic hydrocarbons. I. Benzene, napthalene, anthracene, and phenanthrene, M. E. Wacks and V. H. Dibeler, J. Chem. Phys. 31, No. 6, 1557 (1959).

Value of the Rydberg constant, W. C. Martin, Phys. Rev. 116, No. 3, 654 (1959).

Characteristics of deposits, W. H. Metzger, Jr., Symp. Electroless Nickel Plating, ASTM Spec. Tech. Publ. 265, p. 13 (1959)

Turbulent motion, G. B. Schubauer and C. M. Tchen, Sec. B, Vol. V, Princeton Ser., High Speed Aerodynamics and Jet Propulsion, Turbulent Flows and Heat Transfer, p. 75 (Princeton University Press, Princeton, N.J., 1959).

Confidence intervals for the expectation of a Poisson variable, E. L. Crow and R. S. Gardner, Biometrika 46, 441 (1959).

Electron characteristic energy losses in some intermetallic compounds, B. Gauthe, Phys. Rev. 114, No. 5, 1265 (1959).

Adsorption, diffusion, and evanoration of carbon monoxide or tungsten, R. Klein, J. Chem. Phys. 31, No. 5, 1306 (1959)

The ninth plenary assembly of the CCIR, J. W. Herbstreit, IRE Proc. 48, 45 (1960)

Effect of fluorides on infrared transmittance of certain silicate glasses, G. W. Cleek and T. S. Scuderi, J. Am. Ceram. Soc. 42, No. 12, 599 (1959).

Studies of borate minerals. VI: Veatchite, J. R. Clark, M. E. Mrose, A. Perloff, and G. Burley, Am. Mineralogist 44, No. 11-12, 1141 (1959).

Conditions at the ionization and shock fronts in collisions of gas clouds - Bright rims in diffuse nebulae, Pt. VI, S. R. Pottasch, Rev. Mod. Phys. 30, No. 3, 1053 (1958).

The adhesion of electrodeposited nickel to chromium at elevated temperatures, W. E. Reid, Jr., and F. Ogburn, J. Electrochem. Soc. 10\%, No. 2, 91 (1960).

Chloride content of the diffusion layer at a silver anode, P. A. Krasley, J. Electrochem. Soc. 107, No. 2, 139 (1960).

Spectral emittance of ceramic-coated and uncoated specimens of Inconel and stainless steel, J. C. Richmond and J. E. Stewart, J. Ain. Ceram. Soc. 42, No. 12, 633 (1959).

Chemical structure and stability relationships in polymers, B. G. Achhammer, M. Tryon, and G. M. Kline, Kunststoffe Combined with German Plastics Digest 49, No. 11, 600 (1959); Mod. Plastics 37, No. 4, 131 (1959).

A study of 17-7 pH stainless steel, N. L. Carwile and S. J Rosenberg, WADC Tech. Rep. 58-653 (1959) (Available from the Office of Technical Services, Department of Commerce, Washington 25, D.C.).

High-altitude observation techniques, D. M. Gates, Letter Science 131, 266 (1960).

The relation between confidence intervals and tests of significance - teaching aid, M. G. Natrella, Am. Stat. 14, No. 1, $20(1960)$.

Electrophoretic deposition of metals, metalloids, and refractory oxides, V. A. Lamb and W. R. Reid, Plating 47, No. 3, $291(1960)$.

The effect of the earth's magnetic field on m.u.f. calculations, K. Davies, J. Atmospheric and Terrest. Phys. 16, 187 (1959).

Fusion of polymer networks formed from linear polyethylene: Effect of intermolecular order, L. Mandelkern, D. E. Robberts, J. C. Halpin, and F. P. Price, J. Am. Chem. Soc. 32, $46(1960)$.

Sauter theory of the photoelectric effect, U. Fano, K. W. McVoy and J. R. Albers, Phys. Rev. 116, No. 5, 1147 (1959).

Bremsstrahlung and the photoelectric effect as inverse processes, K. W. MeVoy and U. Fano, Phys. Rev. 116, No. 5, 1168 (1959).
Surface area and exchange capacity relation in a Florida kaolinite, W. C. Ormsby and J. M. Shartsis, J. Am. Ceram. Soc. 43, No. 1, 44 (1960)

Balmer decrements: the diffuse nebulae, S. R. Pottasch, Astrophys. J. 131, No. 1, 202 (1960).

Standard frequency transmission and time signals, W. D. George, Proc. 2d all-IRIG Symp., prepared by Secretariat, Inter-Range Instrumentation Group, Oct. 1958, p. 141, IRIG Document No. 107-58.

Atomistic approach to the rheology of sand-water and claywater mixtures, W. A. Weyl and W. C. Ormsby, ch. 7, Vol. III, Rheology - Theory and applications, Edited by F. R. Eirich, p. 249 (Academic Press, New York, N.Y., 1960).

Diffusion of particles in trubulent flow, C. M. Tchen, Adv. Geophys. 6: Atmospheric diffusion and air pollution, p. 165, Proc. Symp. Oxford, England, Aug. 1958 (Academic Press Ine., New York, N.Y., 1959).

Atmospheric tides and ionospheric electrodynamics, M. L. White, Jr., Geophys. Research 65, 153 (1960)

Some evidence for structural anomalies in pure cristobalite, R. F. Walker, S. J. Schneider, and R. S. Roth, J. Am. Ceram. Soc. 42, No. 12, 642 (1959).

La Recherche sur les radicaux libres au National Bureau of Standards, H. P. Broida, J. chim. phys. 56, No. 2392, 813 (1959).

Isotope exchange processes in solid nitrogen under electron bombardment, R. Klein and E. M. Horl, J. Chem. Phys. 32, No. 1, 307 (1960).

Relative measurement of the photodetachment cross section for $\mathrm{H}^{-}$, S. J. Smith and D. S. Burch, Phys. Rev. 116, No. $5,1125(1959)$

Interference of orbital and spin currents on bremsstrahlung and photoeclectric effect, U. Fano, K. W. McVoy and J. R. Albers, Phys. Rev. 116, No. 5, 1159 (1959).

Use of the equation of hydrostatic equilibrium in determining the temperature distribution in the outer solar atmosphere, S. R. Pottasch, Astrophys. J. 131, No. 1, 68 (1960).

Reception of space diversity transmitters, J. W. Koch, Wireless World (England) 65, No. 10, 512 (1959).

Réactions en chaine de radicaux gelés, J. L. Jackson, J. chim. phys. 56, No. 2392, 771 (1959).

Etude spectrosconique des produits de la decharge electrique dan L'Azote condenses a l'etat solide a tres basse temperature, prevues en faveur de l'existence d'Azote triatomique dan le solide, M. Peyron, E. M. Horl, H. W. Brown, and H. P. Broida, J. chim. phys. 56, No. 2392, 736 (1959).

Apparent temperatures measured at melting points of some metal oxides in a solar furnace, J. J. Diamond and S. J Schneider, J. Am. Ceram. Soc. 43, No. 1, 1 (1960).

Perovskite-type compounds in binary rare earth oxide systems, S. J. Schneider and R. S. Roth, J. Am. Ceram. Soc. 43, No. $2,115(1960)$

Use of disodium $m$-benzenedisulfonate as a hardening agent in Watts nickel bath, W. H. Vetzeer, P. A. Krasley, and F. Ogburn, Plating 47, No. 3, 285 (1960).

On the convergence of the Rayleigh quotient iteration for the computation of characteristic roots and vectors, VI. (Usual Rayleigh quotient for nonlinear elementary divisors), A. M. Ostrowski, Arch. Rat. Mech. Anal. 4, No. 2, 153 (1959).

An analysis of time variations in tropospheric refractive index and apparent radio path len th, M. C. Thompsnn, H. B. Janes, and A. W. Kirkpatrick, J. Geophys. Research 65, $193(1960)$.

Neutron detection by reactions induced in seintillators, C. O. Muehlhause, Pt. I, Fast neutron physics, Sec. III, Pt. III. B, p. 387 (Interscience Publ., New York, N.Y., 1960).

A relationship between the lower ionosnhere and the [OI] 5577 nightolow emission, J. W. McCaullev and W. S. Hough, J. Geophys. Research 64, No. 12, 2307 (1959).

Etude aux infrarouges de certains solides condenses a partir de decharges en phase gazeuse, K. B. Harvey and H. W. Brown, J. chim. phys. 56, No. 2392, 745 (1959).

Theory of flame propagation in solid nitrogen at low temperatures, S. G. Reed and C. M. Herzfeld, J. Chem. Phys. 32. No. 1,1 (1960).

A note regarding the mechanism of UHF propagation beyond the horizon, A. D. Watt, E. F. Forman, and R. W. Plush, Letter Proc. IRE 48, 252 (1960). 
High-frequency limit of bremsstrahlung in the Sauter approximation, U. Fano, Phys. Rev. 116, No. 5, 1156 (1959).

The weighted compounding of two independent significance tests, M. Zelen and L. S. Joel, Ann. Math. Stat. 30, No. 4,885 (1959).

A model of the $F$ region above $h_{\max } F 2, J$. W. Wright, J. Geophys. Research 65, 185 (1960).

Interference of antioxidant in the determination of low polymer in SBR synthetic rubber, L. T. Milliken and F. J. Linnig, J. Polymer Sci. XLI, No. 138, 544 (1959).
*Publications for which a price is indicated (except for NBS Technical Notes) are available only from the Superintendent of Documents, U.S. Government Printing Office, Washington 25, D.C. (foreign postage, one-fourth additional). Technical Notes are available only from the Office of Technical Services, U.S. Department of Commerce, Washington 25, D.C. (Order by PB number.) Reprints from outside journals and the NBS Journal of Research may often be obtained directly from the authors. 